\title{
Sorgulanan Küreselleşme Olgusu, Gelişmekte Olan Ülkeler Açısından Fırsat mı? Tehdit mi?
} (Araştırma Makalesi)

Questioned Globalization Case, Is It an Opportunity or Threat for Developing Countries?

Doi: 10.29023/alanyaakademik.744312

\section{Hüseyin TEZER}

Bilecik Şeyh Edebali Üniversitesi, İ̈BF, İktisat Bölümü

huseyin.tezer@bilecik.edu.tr

Orcid No: 0000-0002-2376-5984

Bu makaleye atıfta bulunmak için: Tezer, H. (2021). Sorgulanan Küreselleşme Olgusu, Gelişmekte Olan Ülkeler Açısından Fırsat mı? Tehdit mi?. Alanya Akademik Bakış, 5(1), Sayfa No. 501 523

Anahtar kelimeler:

İktisat Politikasl, Küreselleşme, Bilgi Ekonomisi, Küresel Ekonomi, Makro Iktisat

Makale Geliş Tarihi: 28.05.2020

Kabul Tarihi: 02.12.2020

Keywords:

Economy Policy, Globalization,

Knowledge Economy, World Economy, Macroeconomy

\section{ÖZET}

Küreselleşme günümüz koşullarında tek boyutta incelenmesi mümkün olmayan, hayatın hemen her alanını etkileyen bir sosyal olgudur. Küreselleşme olgusu, teknolojik yenilikler, bilgiye erişim ve bilginin kullanımı sayesinde dünya ekonomilerinin yakınlaşması veya bütünleşmesi olarak da ifade edilebilmektedir. Yirminci yüzyllın son çeyreğiyle birlikte teknolojiye ve bilgiye ulaşılabilirlikte yaşanan gelişmeler tüm dünya ekonomileri üzerinde farkl etkiler meydana getirmiştir. Küreselleşmenin geldiği bu noktada, iktisat literatüründe yapılan tartışmalar genel olarak iki farklı bakış açısı ortaya çıkarmıştır. Bir taraf, küreselleşmeyi, neoliberal iktisadi politikaların ve teknolojik gelişmelerin itici etkisiyle, ülkelerin refaha ulaşmasında bir firsat olarak görürken, diğer taraf ise, küreselleşmenin ülkeler ve toplumlar arasındaki gelir seviyesi farklılıklarını artıran ve yoksul-zenginlik ayırımını keskinleştiren bir unsur olduğunu ileri sürmektedir. Oysa yirmi birinci yüzyılın başında hızlanan küreselleşme süreci, artılarl ve eksileriyle, avantaj ve dezavantajlartyla, tehdit ve firsatlarıyla beraber aynı anda yaşanan iktisadi bir olgudur. Bundan dolayıdır ki, bu araştırmada, son yillarda hızla yükselen ekonomik küreselleşmenin, serbest piyasalar bağlamında teknoloji ve bilgi ekonomisinin de etkisiyle dünya ekonomileri açısından bir firsat mi, tehdit mi olduğu fikri sorgulanmakta ve gelişmiş ve gelişmekte olan ülkeler bağlamında bir inceleme yapılmaktadır.

\section{ABSTRACT}

Globalization is a social phenomenon that cannot be examined in one dimension in today's conditions and affects almost every area of life. The phenomenon of globalization can be expressed as the convergence or integration of world economies thanks to technological innovations, access to and use of information. With the last quarter of the twentieth century, the developments in technology and information availability have had different effects on all world economies. At this point where globalization has come, 
the discussions in the economic literature have generally revealed two different perspectives. While one side thinking about globalization as an opportunity for countries to reach prosperity with the driving effect of neoliberal economic policies and technological developments, the other side argues that globalization is an element that increases income level differences between countries and communities and sharpens the poorwealth distinction. However, the globalization process, which has accelerated at the beginning of the twenty-first century, is an economic phenomenon that is experienced simultaneously with its pros and cons, advantages and disadvantages, threats and opportunities. Therefore, in this research, the question of whether economic globalization, which has been rising rapidly in recent years, is an opportunity or threat for world economies with the influence of technology and knowledge economy in the context of free markets, and a study is conducted in the context of developed and developing countries.

\section{GİRIŞ̧}

Son yıllarda çok sorgulanan küreselleşme olgusu, dünya ekonomi literatüründe ülkelerin refah seviyesi üzerinde yarattığı sonuçlar bağlamında, yoğunlukla tartışılan konular arasında yer almaktadır. Küreselleşme bir eşitsizlik veya yoksulluk çıkmazı mıdır? Dünyanın küresel bir köye dönüşmesini sağlayan başlıca faktörler, dünyayı düzleştiren gelişmeler nelerdir? Küreselleşmenin ortaya çıkardığı bu farklı yaklaşımlar tüm iktisat literatüründe sorgulanmakta ve yeni cevaplar aranmaktadır. Küreselleşme süreciyle ilgili olarak kuşkusuz en çok tartışılan konulardan birkaçı, gelir dağılımı adaletsizliği, zengin ülkeler ile yoksul ülkeler arasındaki gelir seviyesinin açılıp açılmadığı ve küreselleşmenin yoksulluğa ve eşitsizliğe neden olup olmadığı üzerine olarak örnekler verilebilir. Küreselleşme olgusu, teknolojik yenilikler, bilgiye erişim ve bilginin kullanımı sayesinde dünya ekonomilerinin yakınlaşması veya bütünleşmesi olarak da ifade edilmektedir.

Küreselleşen dünyada "bilgi ekonomisi", bilgi temelleri üzerine kurulan yeni bir ekonomik anlayıştır. Bu kapsamda bilgi ekonomisi birtakım unsurları içinde barındırmaktadır. Bilgi ekonomisinde faaliyetlerin odağında bilgi olduğu gibi rekabet çabalarını şekillendiren temel faktörde bilgidir. Bilgi ekonomisinin en önemli unsurları ise bilgi ve teknolojik seviyedir (Kevük, 2006, s. 322). Dünya ekonomisinin gelişiminde küreselleşme süreci içinde bilgi ekonomisinin etkisinin temel bir sürükleyici güç olarak giderek belirginleştiği açıkça ortaya çıkmaktadır. Bilgi ekonomisinin bu etkisi hızla artmaya devam etmekte ve dünya ekonomisinin şekillenmesinde derinlere inen, bugüne kadar gerçekleşenlerden çok daha kapsamlı dönüşüm ve değişim süreçlerini harekete geçirmektedir (Işık, 2007;1). Gerek uluslararası ilişkilerde gerekse günlük yaşantıda değişimlerin etkisinin belirgin bir şekilde hissedildiği dünyada, ulaşım, iletişim ve bilgi işlem teknolojilerindeki hızlı gelişmelerin tetiklediği küreselleşme sayesinde dünya yüzeyi bir köy haline gelmiştir. Ancak bu hızlı değişim ve dönüşümün her ülke için aynı oranda olduğunu söylemek zordur. Özellikle finansal piyasalardaki serbestleşme ve teknolojik ilerlemelerin katkısıyla dünyaya yayılan küreselleşme olgusu gelişmiş, az gelişmiş ve gelişmekte olan ekonomiler arasındaki gelişmişlik farklarını artırmaya devam etmektedir (Acar, 2018, s. 29). Küreselleşen dünya ekonomisinde rekabet gücü, yeni teknolojiler üretme ve bu yeni teknolojileri hızla yeni ürünlere ve üretim süreçlerine dönüştürme yeteneğine bağlıdır. Teknoloji açığını dişarıdan transfer etmek yerine teknolojiyi üretme kabiliyetine sahip olan ekonomiler her zaman bu 502 
üstünlüğe sahip olmuşlardır. Diğer yandan teknoloji ve bilgi ekonomisindeki gelişmeler, küreselleşme üzerinde yapılan tartışmaları iki farklı bakış açısına yöneltmiştir. Bir taraf küreselleşmeyi, neoliberal iktisadi politikaların ve teknolojik gelişmelerin itici etkisiyle, ülkelerin refaha ulaşmasında bir firsat olarak görürken, diğer taraf, küreselleşmenin ülkeler ve toplumlar arasında gelir seviyesi farklılıklarını artıran zengin ve yoksul ülke ayırımını keskinleştiren bir unsur olduğunu ileri sürmektedir. Hatta tartışmalar öyle boyutlara varmıştır ki; küreselleşme, zengini daha zengin, fakiri ise daha fakirleştiren, ülkeler arasındaki gelir dağılımı adaletsizliğini artıran bir süreç olarak görülmektedir. Oysa küreselleşme süreci, artıları- eksileriyle, avantaj-dezavantajlarıyla, tehditleriyle- firsatlarıyla beraber aynı anda yaşanan küresel bir olgudur. Dünya ekonomisinde ekonomiler arasındaki farklılaşmanın nedenlerinin başında finansal kaynakların eksikliği, yatırımların azlığı ve teknolojik bilgilerin yetersizliği gelmektedir. Küreselleşmeye olumlu bakan iktisatçılar, bu dönüşümü, az gelişmiş ve gelişmekte olan ekonomilerin büyüme ve kalkınmalarının önündeki engellerle mücadele etmesini kolaylaştıran bir unsur olarak görmektedirler. Küreselleşmenin getirdiği olanaklar sayesinde iç kaynakların yetmediği durumlarda diş kaynaklara başvurarak teknolojik bilgi ve sermaye transferleri yapmaları daha kolay hale gelmekte ve küreselleşme sayesinde ekonomik kalkınma ve büyüme imkanlarına kavuşmasını kolaylaştırmaktadır. Küreselleşme karşıtı olan görüş ise, sermayenin ve malların hareketliliğinin, teknoloji, iletişim, ulaşım ve bilgi ekonomisinde görülen gelişmelere rağmen, küreselleşmenin kurallarının küresel şirketler tarafından belirlenen bir dünya düzeni olarak görülmektedir. Bu yüzden küreselleşme, kural koyucuların lehine bir düzen meydana getirirken, bu kurallara boyun eğen diğer kesimler açısından olumsuz sonuçlar meydana getirmektedir. Fakat bütün bu gelişmelere rağmen, iletişim, ulaşım ve bilgi ekonomisindeki gelişmeler sonucu ekonomik ve kültürel sınırların ortadan kalkması ve dünyevi yaşayışların birbirine yakınlaşması, toplumları da birbirine daha bağımlı hale getirmiştir. Bundan dolayıdır ki, bu araştırmada, son yıllarda hızla yükselen ekonomik küreselleşmenin boyutları, teknoloji ve bilgi ekonomisinin dünya ekonomisi dinamikleri üzerindeki etkisi araştırılmakta ve dünya ekonomileri açısından küreselleşmenin ve bilgi ekonomisinin etkileri ve sonuçları bağlamında değerlendirmeler yapılmaktadır. Çalışmanın araştırma düzlemi, serbest piyasa ekonomi anlayışının hızlandırdığı küreselleşme olgusunun ve teknoloji ve bilgi ekonomisinde görülen gelişmelerin, dünya ekonomisindeki farklı gelir gurupları ve seçilmiş örneklem ülkeler üzerindeki sonuçları hakkındadır. Küreselleşmenin ve bilgi ekonomisinin itici kuvvetinden faydalanan farklı gelir seviyesindeki ekonomilerin yirmi birinci yüzyılın ilk çeyreğinde yakalamış oldukları yeni bilgi ve teknolojik imkanlar sayesinde eriştikleri ekonomik gelir seviyesinin nedenleri ve sonuçları sorgulanmaktadır. Araştırmanın bir diğer sorgusu ise gelişmiş ekonomilerin, dış ticarette yükselen yeni ekonomilere karşı teknolojik ürünlerde rekabet avantajlarını kaybetmekle beraber hala dünyanın merkezinde ve dünyanın en büyük ekonomileri arasında olmayı nasıl sürdürebildiklerinin de incelenmesidir. Araştırma verileri dünya ekonomisinin geneli üzerinden sermaye hareketleri, Küresel Bilim ve Teknoloji Göstergeleri; (Bilimsel Yayınlar, Küresel Patent Başvuruları, Araştırma ve Geliştirme Harcamaları AR-GE, Yüksek Teknoloji Harcamaları, Marka Tescil Başvuruları, Endüstriyel Tasarım Başvuruları), Dış Ticaret Büyüklükleri, GSYH Büyüklük istatistikleri, gibi göstergelerden yola çıkarak küreselleşmenin dünya ekonomileri üzerinde örneklem yapılan ülkeler ve gelir guruplarının karşılaştırması yapılarak küreselleşmenin ekonomik sonuçları üzerinde bir değerlendirmeyle sonuçlandırılmaktadır. 


\section{KÜRESELLEŞME OLGUSU VE KÜRESELLEŞME ÜZERINDE FARKLI YAKLAŞIMLAR}

"Küreselleşme" sosyal bilimlerde moda bir kavram olarak yönetim guruplarının reçetelerindeki ana buyruk ve farklı taraflardan gazeteci ve politikacılar için gündemi yakalama sözcüğü haline gelmiştir. Yaygın sava göre, ulusal kültürlerin ve ulusal ekonomilerin çözüldüğü, sosyal hayatın büyük bölümünün küresel süreçler tarafından belirlendiği bir çağda yaşanılmaktadır. Bu anlayışın merkezinde, yeni ve hızlı ekonomik küreselleşme süreci fikri yatmaktadır. Ayrı ulusal ekonomilerin ve dolayısıyla ulusal ekonomik yönetiminin yerli stratejilerinin hızla geçerliliğini kaybettiği gerçek bir küresel ekonominin ortaya çıktığ 1 ya da çıkma sürecinde olduğu ileri sürülmektedir (Hirst \& Thompson, 2007, s. 26). Kimilerine göre küreselleşme çağdaşlaşma ve gelişme demekken, kimilerine göre küreselleşme emperyalizmin yirmi birinci yüzyıldaki adıdır. Kimilerine göre küreselleşme Batı'nın demokrasi ve insan haklarına dayanan değerlerini az gelişmiş ülkelere taşıyan bir süreçken, kimilerine göre ise küreselleşmenin getirdiği demokrasi ve insan hakları gibi kavramların bir yanıltmasıdır. Kimilerine göre dünya kaynaklarının en akılcı ve en verimli biçimde kullanılması iken, kimilerine göre ise küreselleşme Batı'nın ekonomik düzeni olan kapitalizmin dünyayı pazar yapma aracıdır (Göngen, 2013, s. 118). Bir başka bakış açısında ise küreselleşme; ekonomik, siyasi, sosyal ve kültürel alanlarda bütünleşmenin gelişmesi ve bazı ortak değerlerin yerel ve ulusal sınırları aşarak dünya çapında yayılmasını ifade etmektedir. Ekonomik alanda hem gelişmiş hem de gelişmekte olan ülkelerde benimsenen ekonomik sistem ve uygulanan ekonomi politikaları giderek birbirine benzemektedir (Adıgüzel, 2011, s. 57). Bir başka bakış açısında ise küreselleşme; "ülkeler arasındaki ekonomik, siyasi, sosyal ilişkilerin yaygınlaşması ve gelişmesi, ideolojik ayrımlara dayalı kutuplaşmaların çözülmesi, farklı toplumsal kültürlerin, inanç ve beklentilerin daha iyi tanınması, ülkeler arasındaki ilişsilerin yoğunlaşması gibi farklı görünen ancak birbiriyle bağlantılı olguları içeren, bir anlamda maddi ve manevi değerlerin ve bu değerler çerçevesinde oluşmuş birikimlerin milli sınırları aşarak dünya çapında yayılması" anlamına gelmektedir (Çiğdem, 2014, s. 8). Küreselleşme, yerel olayların millerce ötedeki olaylar tarafından biçimlendirildiği bağlantılar kuran dünya çapında toplumsal ilişkilerin yoğunlaşması olarak tanımlanabilir. Bu diyalektik bir süreçtir. Çünkü böylesi yerel olaylar kendilerini biçimlendiren uzaktaki olayların tam tersi yönde ilerleyebilirler. Yerel dönüşüm küreselleşmenin zaman ve mekan boyunca toplumsal bağlantıların çok taraflı artışının bir parçasıdır (Giddens, 2014, s. 81). Bilginin üretilmesi ve yaygınlaşmasında etkin olan teknolojik gelişme ise, bilişim ve teknolojide görülen hızlı gelişmelerdir. İnternet, ulaşım, bilgi ekonomisi ve iletişim teknolojilerindeki yeniliklerin dünyada yaygınlaşması yalnızca nicel anlamda mesafeleri kısaltmamakta, aynı zamanda mekan kavramını da niteliksel anlamda bir dönüşüme uğratmaktadır (Acar, 2018, s. 27). Küreselleşmenin hızla yükseldiği dünyada bilginin bu kadar hızlı yayılması ve yeni bilgilerin sürekli yenilenmesi nedeniyle bu çağa "Bilgi Çağı" denmektedir. Bilgiyi daha çok elinde bulunduran ekonomiler, toplumlar, örgütler, bir yandan bilgi çağının güç merkezlerini, öte yandan da bilimin ana konularını belirleyen odaklar haline gelmektedirler. Bilgi çağıyla eş zamanlı ortaya çıkan ve bilginin küresel dünya üzerinde daha geniş alana yayılmasına firsat veren, bir yandan bilgi üretimini körükleyen diğer yandan ise bilgi üretimiyle körüklenen küreselleşme süreci, bilginin güç merkezleri tarafindan dünyaya yayılmasına ve bilginin tüm dünyada farklı etkiler yaratmasına neden olmaktadır (Karg1, 2006, s. 9). Günümüzdeki ekonomik yaşam daha önce hiçbir dönemde görülmediği kadar hızlı ve geniş kapsamlı bir biçimde dönüşmektedir. Toplumların 
refah seviyesini artıracak şekilde ivme kazanan bu dönüşümün temel dinamiği ise bilgi olgusunun fonksiyonlarındaki gelişmelere dayalıdır. Bilginin işlenmesi, depolanması ve aktarılması fonksiyonlarını etkinleştiren bilgi sektörü, ekonomi üzerindeki payını artırarak refah seviyesindeki yükselişleri pozitif yönde etkilemektedir (Karahan, 2006, s. 91). Dünya ekonomisinde öne çıkan ve bilgi ekonomisi olarak tanımlanan sürükleyici ekonomik, sosyal ve yönetişimsel yapıya uygun dönüşümleri sağlayan kapsamlı politikalar demetidir. Burada geniş sınırlar çerçevesinde tanımlanmış olan bu alanlar bir ülkenin yüksek performansa ulaşması bakımından birbirlerine yakından bağlıdır. Bu çerçevede ilk üç alanda aksayan ülkeler bilgi ekonomisine dönüşememektedir. Bu sonuçta dünya ekonomisinde gelişme performansları başarılı olan ülkeler aynı zamanda bilgi ekonomisine dönüşümde ileri aşamalara varan ülkelerdir. Bilim ve iletişim teknolojilerindeki olağanüstü ilerlemenin de etkisiyle sayısallaşmanın yaşamdaki faaliyet alanlarının çok büyük bölümünü kapsayacak biçimde gelişmesi tüm dünya açısından bilgi ekonomisine dönüşüm ve bu doğrultudaki gelişme sürecinin öneminin belirginleşip artırmaktadır (Işık, 2007;3). Küreselleşmenin etkisinin hızla yayıldığ 1 dünyada ekonomik ve sosyal kalkınma açısından bilgi ve iletişim teknolojileri artık bir ön koşul haline gelmiş ve iletişim teknolojileri bir taraftan ülkelerin üretim sistemlerini modernleştirip rekabet güçlerini hızla yükseltirken, diğer taraftan ise bu yeni teknolojilere yetişemeyen ülkelerin diğerleriyle arasındaki gelişmişlik seviyelerinin de hızla bozulmasına neden olmuştur (Karg1, 2006, s.1). Teknolojik gelişmelerin hızlanmasıyla ivme kazanan uluslararası sermaye hareketliliğinin varlığının, tasarrufların yetersiz olduğu ekonomilerde sermaye eksikliğinde yaşanan açıkların giderilmesinde etkin rol oynadığı söylenebilir. Uluslararası sermaye hareketleri; portföy yatırımları ve doğrudan yatırımlar şeklinde ortaya çıkmaktadır. Belli bir risk üstlenerek bir başka ülkeden tahvil, hisse senedi ya da borç senedi gibi finansal varlıkların satın alınması şeklinde oluşan portföy yatırımları herhangi bir risk ya da istikrarsızlık gördükleri durumda giriş yaptıkları ülkeyi terk edebilmektedir. Daha düşük maliyetlerle çalışabilmek için üretim faktör fiyatlarının nispeten daha ucuz olduğu iç talebin ve altyapının yeterli bulunduğu ülkeleri daha çok tercih etmekte olan doğrudan yabancı yatırımlar, gittikleri ülkelerde istihdam, döviz, know-how gibi çeşitli alanlarda büyük avantajlar sağlamaktadır (Ozcağ vd. 2019;42). Doğrudan yabancı yatırımlar, giriş yaptıkları ülkede çeşitli etkiler yaratmaktadır. Sadece yatırım ve sermaye stokunu artırmakla kalmayıp, aynı zamanda yeni üretim kapasitesi yaratarak istihdam artışına da olumlu katkılar yapar. Bununla beraber teknoloji ve yönetsel beceriler gibi maddi olmayan varlıkları da ev sahibi ülkeye transfer etmek gibi önemli bir avantaj sağlamaktadır (Ozcağ, 2019;43). Özellikle 1990'dan sonra gelişmiş ülkeler çeşitli fonlarda biriken kaynaklarını gelişmekte olan ülkelere aktarıp yüksek getiriler elde etmişlerdir. Gelişmekte olan ülkeler yabancı sermayeyi ülkelerine çekebilmek için göreli olarak daha yüksek oranlı faiz uygulamaları ile beraber ortaya çıkan sorun ulusal paranın aşırı değer kazanmasıdır. Bu durum ihracatı azaltırken ithalatı artırarak ülkenin dış açığını artırıcı etki yaratacaktır. Öte yandan böyle bir durumda dolaylı yabancı sermayenin elde edeceği getiri ve dolayısıyla da kaynak transferinin miktarı kur etkisine bağlı olarak artmaktadır. Yatırımların küreselleşmesiyle kastedilen doğrudan yabancı sermaye yatırımlarıdır ve bir yönüyle de üretimin küreselleşmesini ifade etmektedir (Şanlısoy, 2016;2194). Küreselleşme ya da dünya ekonomilerinin daha yakın entegrasyonu. Ulaşım ve iletişim masraflarının düşmesi küreselleşmeyi ne kadar teşvik ettiyse oyunun kurallarındaki değişimler de bir o denli etkili olmaktadır. Ticaretin ve sermayenin ekonomiler arasındaki akışının önündeki engellerin azaltılması öne çıkan unsurdur. Örneğin Çin mallarına uygulanan tarifelerin düşürülmesi ve bu malların Amerikan mallarıyla neredeyse eşit bir oyun alanında rekabet etmesi 
küreselleşmenin nimetlerinden görülmektedir (Stiglitz, 2012, s. 114-115). Küresel eşitsizlikteki azalmaya ilişkin göstergeler özellikle Asya'daki gelişmelerden örneklerle açıklanabilir. Özellikle 2000'lerden itibaren Çin ve Hindistan ile Asya pasifik ülkelerindeki yüksek GSYH büyüme oranları bunu açıkça göstermektedir (Milanoviç, 2018, s. 130-131). Çin'deki büyüme aksamalar gösterse bile Hindistan, Endonezya, Bangladeş, Tayland, Vietnam gibi nüfusları yüksek olan Asya ülkelerindeki hızlı ekonomik büyümeye devam etmektedir. Yirmi birinci yüzyıl başlarına kadar küresel yoksulluk ve eşitsizliğin azalmasına katkısı olan en önemli ülke Çin olmasına rağmen, yirmi birinci yüzyıldan itibaren özellikle Asya pasifik ülkelerin başını çekeceği yüksek ekonomik performanslara sahne olan küresel bir yansıma olacaktır. Dünyada ekonomik güç daha çok Asya'ya doğru kayacaktır (Milanoviç, 2018, s. 229).

\section{KÜRESELLEŞMENIN TARİHSEL SÜRECINE BAKIŞ}

Küreselleşmenin tarihsel başlangıcı ile ilgili literatürde genel bir mutabakat yoktur. Bazılarına göre küreselleşmenin insanlık tarihi kadar eski olduğu ileri sürülürken, bazılarına göre ise küreselleşmenin modern çağın başlangıcını, bazılarında ise 1800'lerin başından itibaren, yine bir başka görüşe göre ise küreselleşmenin başlangıc1 1950'lerin sonları ya da 1970'lerin başlarına dayanmaktadır (Göngen, 2013, s. 123). Küreselleşmeye dair kamusal referansların son yirmi yıl boyunca artan bir şekilde yaygınlaşmasına rağmen kavramın kendisi çok daha eski dönemlerden gelmiştir. Kavramın kökleri, Saint-Simon ve Karl Marx’tan modernitenin dünyayı nasıl bütünleştirdiğini fark eden MacKinder gibi jeopolitik öğrencilerine kadar on dokuzuncu ve yirminci yüzyıl başı entelektüellerinin çalışmalarına kadar uzanmaktadır. Fakat "küreselleşme" terimi, 1960'lar ve 1970'lerin başlarına kadar bugünkü anlamıyla kullanılmamıştır (Held \& Mc Grew, 2014, s. 7-8). Küreselleşmenin ekonomi tarihinde, Amerika'nın keşfedilmesi, Asya ile dünyanın geri kalanını bütünleştiren alternatif yolların bulunuşu, Afrika kıtasındaki doğal kaynakların, dünyanın kullanıma açılması gibi işlemler yaşanmıştır. Buhar gücünün kullanımı, mekanik teknolojilerin gelişimine öncülük ederken; elektronların telli ya da telsiz ortamlarda transmisyonu; küreselleşmenin bu günündeki temel destekleyici unsurları olmuştur (Alkan, 2009, s. 227). Birinci endüstri devrimi ile başlayan ve günümüze kadar süren son iki yüz yıllık dönemde ekonomik, toplumsal, kültürel ve politik yapılar önemli değişiklikler geçirmiştir. Bu süreçte başta teknolojik gelişmeler olmak üzere birçok faktörün etkisi ile dünyada ekonomik, siyasal, sosyal ve kültürel bir bütünleşme süreci yaşanmış ve yaşanmaktadır (Adıgüzel, 2011, s. 57). Sanayi devrimiyle birlikte, ulaşım ve iletişim teknolojisindeki gelişmelerinde etkisiyle sömürgeci ülke, sömürülen ülke ile olan bağlarının kuvvetlendirilmesi sonucu aralarındaki dış ticareti, kota ve gümrük vergisi gibi kısıtlamaları da ortadan kaldırmıştır. Bu uygulama serbest diş ticaret anlayışı sömürge ülkelerini pazar ve ham madde kaynağı haline dönüştürmüştür. Bu dönemdeki sömürgeci ve sömürülen ülkeler arasındaki ilişkiler küreselleşmeyi hızlandıran bir faktör olmuştur (Göngen, 2013, s. 123-124). On dokuzuncu yüzyılın adı ise değişim yüzyılıdır. Bu dönemde dünya kapitalizminin merkezini oluşturan "Kuzey Atlantik" kıyısındaki dinamik bölgelere bağlı ve bu bölgelerin amaçlarına uygun düşen nitelikte bir değişim olmuştur. Sayıları giderek azalan bazı önemsiz istisnalar bulunmakla beraber, bütün ülkeler, hatta o zamana dek en yalıtılmış durumda olanlar bile, bu küresel dönüşümün dokunaçları tarafindan en azından dışarıdan sımsıkı sarılmışlardır. Oysa diğer yandan gelişmiş ülkelerin en ileri olanları bile kısmen eski ve geri bir geçmişin mirasını (günümüze) uyarlamak suretiyle değişmişlerdir. Ancak içlerinde değişime direnç gösteren toplumsal tabakalar ve kesimler de barındırmaya devam etmişlerdir (Hobsbawn, 2017, s. 35). İkinci dünya savaşı sonra bir yandan çok uluslu 506 
şirketlerin ortaya çıkması, bir yandan da uluslararası ticaretin çok hızlanması küreselleşmeyi hızlandıran bir etki yaratmıştır. 1971-73 döneminde Bretton-Woods yarı sabit döviz kuru rejiminin çöküşüyle birlikte, sermaye piyasaları hızla uluslararasılaşırken, uluslararası menkul kıymetler yatırımlarının ve banka kredilerinin yaygınlaşma süreci de hızlanmıştır. Bu süreç, uluslararası ekonomik ilişkilerin karmaşıklaşmasına da katkıda bulunmuş, bütünleşmiş ve bağımlı bir dünya ekonomisinin gerçek anlamda küreselleştiğinin habercisi olmuştur (Hirst \& Thompson, 2007, s. 44). Bretton Woods para rejiminin, sermayenin uluslararası alanda daha devingen olmasıyla ve 1970'lerin petrol şoklarının gelişmiş ülkeleri sarmasıyla birlikte savunulamaz olduğu görülmüştür. Hiper küreselleşme olarak adlandırılan yapıyı kurabilmek için 1980'ler ve 1990'larda daha azimli bir ekonomik liberalleşme ve derin entegrasyon dönemi olmuştur. Ticaret anlaşmaları, ithalat kısıtlamaları konusundaki geleneksel bakış açısının ötesine geçilmiş ve yerel politikalar aşılmıştır. Uluslararası sermaye piyasaları üzerindeki kontroller kaldırılmış ve gelişmekte olan ülkeler yabancı ticaret ve yatırım piyasalarını dışa açma konusunda büyük bir baskıya maruz kalmıştır (Rodrik, 2011, s. XVI). Başkaya'ya göre 1980'lerin başında ortaya çıkmaya başlayan küreselleşme olgusu, yeni eğilimleri ve süreçleri tanımlamak için kullanılmaktadır. Türkçedeki küreselleşme kavramı, artık dünyanın "lingua franc'sı" durumuna gelen İngilizcedeki (Amerikancadaki demek daha uygun) 'globalization', Fransızcadaki 'mondialisation'un karşılığı olarak kullanılmaktadır (Başkaya, 2015, s. 79). Son yıllarda hızla karmaşıklaşan finansal küreselleşme daha fazla yatırım ve hızlı büyüme yerine istikrarsızlığa neden olmuştur. Ülkeler içinde küreselleşme, gemileri su yüzüne çıkarmak yerine eşitsizlik ve güvensizlik yaratmıştır. Bu dönemde özellikle Çin ve Hindistan'da muazzam başarılar elde edilmiş, ancak, bu ülkeler küreselleşme oyununu yeni kurallara göre değil, Bretton Woods kurallarına göre oynamayı tercih etmişlerdir. $\mathrm{Bu}$ ülkeler kendilerini hiç koşulsuz uluslararası ticaret ve finansal imkanlara açmak yerine, ekonomilerini çeşitlendirmek için ağır bir devlet müdahalesiyle karmaşık stratejiler izlemişlerdir (Rodrik, 2011, s. XVI). Çin, Hindistan gibi yükselen ülkeler, bilgi ekonomisi odaklı gelişmelerden yararlanma ve bu sürece katılma yolunda önemli adımlar atmışlardır. Bir ülkenin önemli ölçüde bilgi ekonomisine yakınsaması yalnızca teknoloji temelli ürünler üretmesiyle değil ülkenin ve ülke nüfusunun büyük bir çoğunluğunun bilgiye dayalı üretim sürecine girmiş ve kapasiteyi geliştirmiş olması gerekmektedir. Diğer taraftan bilimsel ve teknolojik gelişmeye dayalı üretimin gelişmesinin ve bu kapasitenin rekabet gücünün önemli bir bileşenini oluşturmasının bilgi ekonomisinin geneline yönelim sürecinin son derece önemli bir bileşenini oluşturduğu da belirtmelidir (Işık, 2007;5). Yeni teknolojilerin gelişmesi ve uluslararasında yayılmasının önemi, Avrupa'nın ve ABD'nin on dokuzuncu yüzyıldaki sanayileşmesinde ve daha da çarpıcı bir şekilde Japonya'nın da yirminci yüzyıldaki sanayileşmesinde, tarihsel olarak, çok iyi bilinen bir gerçekliktir. Bu gerçekliğin önemi, günümüzde bazen "yeni sanayileşen ülkeler” bazen de "dinamik Asya ekonomileri" diye adlandırılan Güney Kore, Honk-Kong, Tayvan, Singapur, İrlanda ve son zamanlarda Hindistan, Çin, Malezya, Tayland ve Endonezya'nın hızla sanayileşmesi ile daha güçlü bir şekilde kanıtlanmaktadır (Freeman \& Soete, 2003, s. 401). İletişim ve ulaşımdaki olağandışı hızlanmanın paradoksal bir sonucu olmuştur. Bu yeni teknolojiye sahip yerlerle diğerleri arasındaki uçurumun büyümesine paralel olarak, ulaşımın hızının hala ata, öküze, katıra, hamallara ya da sallara bağlı olduğu dünyanın diğer kesimlerindeki toplumlarla arasındaki göreceli gelişmişlik düzeyleri daha çok artmaktadır (Hobsbawn, 2017, s. 74). Toffler (1980), "Üçüncü Dalga" kitabında küreselleşen dünya ekonomi tarihini üç dalgalı döneme ayırmaktadır. Birinci dalgada toplumlar büyük ölçüde kendi ürettiklerini tüketirler ve onlara üreten tüketiciler denmektedir. İkinci dalgada ise işlerin tersine döndüğünü ve artık 
toplumlar kendi ürettiklerini tüketen toplumlardan pazar için üreten toplumlara dönüştüğünü ileri sürmektedir. Ekonomi kelimesi bile pazara sürülmek amacıyla üretilmeyen ürün ve hizmetleri kapsamayacak şekilde yeniden tanımlanmıştır. Üçüncü dalgada ise dünya ekonomisini yeniden biçimlendiğini ve meslek olarak ekonomi, bilgisayarlaştırılmış modellerle bile olanı biteni açıklamayı başaramadığı bir sisteme dönüştüğünü ileri sürmektedir.

\section{4. İKTİSAT LITERATÜRÜNDE KÜRESELLEŞME}

Küreselleşmeyle ilgilenen birçok kesim-medya araştırmacı ve uzmanları, ekonomi operatörleri ve sendikalar, bakanlar ve hükümet başkanları, uluslararası kuruluşların temsilcileri ve çıkar gurupları arasında en az dört farklı konum seçilebilir. İlk sıradakiler küreselleşmeyi yalnızca yarar getirerek dünyayı değiştirmekte olan karşı konulmaz bir süreç olarak görmektedirler. Her ne kadar bu konuda kuşku duyanların sayısı doksanlı yılların sonunda artmış da olsa, 2000'li yıllarda bu düşünce hala oldukça yaygındır. İkinci sıradakiler küreselleşme konusunda tam tersine bir düşünceyle küreselleşmeyi küçümser ve önemsizleştiren bir görüştedirler. Üçüncü sıradakiler ise Güney Asya, Güney Amerika ve Rusya'da ortaya çıkan 1997-98 ekonomik krizlerinden sonra artan ve sürmekte olan küreselleşmenin olumsuz yönlerini öne sürmektedirler. Son sırada olanlar ise küreselleşmenin hem olumlu hem de olumsuz yönleri olduğu gerçeğinden hareketle araştırmacı bir eğilim ortaya koymaktadırlar (Gallino, 2012, s. 76-77).

Küresel ekonomik bütünleşme gelir, kültür, toplum ve çevre üstünde karışık sonuçlar yaratmıştır. Küreselleşmenin faydaları üzerine olan tartışmada onun yoksullaşma üzerindeki etkisi önemlidir. Eğer uluslararası yatırım ve ticaret temel olarak zengin için faydalı ise birçok kesim sınırlı ticareti, kültürü ve çevreyi korumak için bu bedeli ödemeye razı olacaktır. Yine de eğer sınırlı ticaret, kalkınmakta olan ekonomilerde yoksulluğu daha fazla artırıyorsa, bu seferde tam aksi yönde bir kabulleniş olacaktır. Son iki asır dünya ekonomisinde yerel ekonomiler daha fazla bütünleşirken, küresel ekonomilerinin ekonomik büyüme oranları da çarpıcı bir şekilde artmıştır. Ulaşım ve iletişim teknolojilerinin içerdiği yenilikler, maliyetleri düşürmüş ve bütünleşmeyi artırmıştır. Bu iki olgu dünya ekonomisindeki büyüme rakamlarını da olumlu yönde etkilemiştir (Dollar \& Kraay, 2014, s. 530-531).

Yirminci yüzyılın ikinci yarısında ortaya çıkan ekonomik, sosyal, kültürel, ekolojik ve teknolojik gelişmeler, toplumların alışkanlıkları yaşam tarzları ve gereksinimleri üzerinde önemli değişimler meydana getirmiştir. Küreselleşme sürecinde bu bakış açısıyla ekonomik, sosyo-kültürel ve siyasal dünyayı içine alan değişim bağlantılar şeklinde kabul edecek olursak, küreselleşmenin bu değişim ve gelişim süreçleri içindeki önemi daha fazla belirgin bir hale gelecektir (Çelik, 2012, s. 58).

Dünyayı tek pazar haline getirebilmek için kapitalizm, küreselleşme söylemini, emperyalizm karşısında çaresizlik yaratmak ve ona saygınlık yaratmak için kullanmıştır. Bu gelişmeler içinde sermaye tamamen kozmopolit ve vatansız hale dönüşmüştür. Son yıllarda spekülatif sermaye hareketleri tamamen serbest kalmış ve kısa vadeli sermaye hareketleri uzun vadeli sermaye yatırımlarının önüne geçmiştir. Sermaye hiçbir sınır tanımadan, neredeyse anında, nerede çok kâr varsa oraya yönelme imkanına kavuşmuştur (Köseoğlu, 2002, s. 115).

Küreselleşmenin kapsamlı sürecinin bazı nedenlerden dolayı ulusal farklılıklarının devamlılığına veya buna bağlı olarak ulusal özellikler üzerinde olumsuz etkiler yaratabilir. Bu 
olumsuzluklar iki şekilde kendini gösterebilir. Farklı ülkelerdeki kültürlerin ve geleneklerin homojenleşmesinde artış ya da her ülke içindeki belirli kültürel ve geleneksel dokunun parçalanması şeklinde ortaya çıkabilir (Bronk, 2010, s. 225).

Küreselleşme söyleminin Batı'daki kuvvetli toplumsal güçlerin çıkarlarına çok iyi hizmet edebildiği reddetmezken, aynı zamanda küreselleşmeci açıklama, modern toplumsal örgütlenme ölçeğindeki gerçek yapısal değişimleri de yansıttığını vurgular. Diğer gelişmelerin yanında, çokuluslu şirketlerin artış1, dünya mali piyasaları, popüler kültürün yayılması ve çevrenin küresel olarak yok oluşu bunun kanıtıdır. Küreselleşmeyi salt bir ekonomik görüngü olarak kabul etmek yerine, küreselleşmeci analiz toplumsal ilişkilerin diğer önemli boyutlarını eşit statüde görür (Held \& Mc Grew, 2014 s. 7-8).

Küreselcilik kıtalararası mesafelerde karşılıklı bağımlılık şebekeleri içeren bir dünya durumu ifade etmektedir. Sermaye ve malların, haber ve fikirlerin, insan ve güçlerin, çevresel ve biyolojik açıdan önemli maddelerin asit yağmurları ve patajenler gibi akış ve etkileri aracılığıyla gerçekleşiyor. Küreselleşme ve küreselleşmenin terse çevrilmesi küreselciliğin artış ve azalışını ifade etmektedir. Karşılıklı bağımlılık ülkelerin ya da farklı ülkelerdeki oyuncuların karşılıklı etkileri ile ayırt edilen durumları ifade etmektedir. Bu yüzden küreselcilik bir çeşit karşılıklı bağımlılıktır (Keohane \& Nye, 2014, s. 97).

Küreselleşmenin getirdiği fırsatların başında, yararlanmasını bilenler için, hızlı ekonomik büyüme ve kalkınma firsatı gelmektedir. Günümüzde istisnasız her ülke ekonomisi, ulusal gelir hesaplarında hızlı artışlar gerçekleştirmek, pastayı büyütmek, vatandaşlarının refah seviyesini yükseltmek, kalkınma yarışında hızla ilerlemek ve gelişmiş ülkeler arasına katılmak istemektedirler (Acar, 2018, s. 171).

Sermaye piyasaları küresel anlamda karşılıklı olarak birbirine bağımlıdır ve bu durum kapitalist bir sistemde sorun teşkil etmemektedir. Sermaye tarihte ilk kez gerçek zamanlı çalışan, küresel anlamda bütünleşmiş mali piyasalarda gece gündüz yönlendirilebilmektedir. Tüm dünyada elektronik devrelerde saniyeler içinde milyarlarca dolar iş gerçekleşebilmektedir. Yeni enformasyon sistemleri ve iletişim teknolojileri sermayeye ekonomiler arasında çok kısa sürelerde mekik dokuma imkanı sağlamaktadır. Sermaye ve ondan dolayı tasarruf ve yatırımlar dünya ölçeğinde, bankalardan emekli fonlarına, borsalara ve döviz alım-satımlarına kadar hepsiyle bağlantılıdır. Bu nedenle küresel mali akışlar hacim olarak, hız olarak çarpıcı avantajlar sunabilmektedir (Castells, 2014, s. 367-368).

Çağımızın uluslararası ekonomik yapılanmasında önemli değişiklikleri simgeleyen küreselleşme olgusu ulusal mali sistem ve felsefede de çok ciddi değişimlere neden olmuştur. Ulus devlet sınırları içinde oluşan değişimlerin 1970'lerin ortalarından itibaren ulus ötesine taşınmasına yol açan merkez kapitalist ekonomilerdeki kâr sıkışıklığı, ulusal kamu kesimi yapılarına da yansıyarak vergi ve harcama politikalarında ciddi değişimlere neden olmuştur. Küreselleşme olgusu çerçevesinde ulusal ekonomilerin hareket ve etki kabiliyetinin ulusal sınırların ötesine taşınmasına bağlı olarak, üretici altyapının kamu kesimi ve politikaları üzerindeki etkisi de hükümetlerin göreli bağımsızlık sınırlarını daraltırcasına ulus devlet dönemindekine oranla çok daha güçlü olmuştur (Önder, 2011, s. 47-48).

$\mathrm{Bu}$ yeni binyıl dönümünde yeni bir dünya şekilleniyor. Bu yeni dünyanın kökleri 1960'ların sonunda, 1970'lerin ortalarında üç bağımsız sürecin tarihsel olarak bir araya gelmesine uzanmaktadır. $\mathrm{Bu}$ süreçler enformasyon (Knowledge) teknolojisi devrimi; kapitalizmin de devletçiliğin de ekonomik krize girmesi ve peşinden yeniden yapılanmaları ve liberalizmin, 
insan hakları, feminizmin ve çevrecilik gibi kültürel ve toplumsal hareketlerin yeni bir oluşum haline gelmesidir. Yeni bir ekonomi, enformasyonel / küresel ekonomiyi ve yeni bir kültürü ve gerçek sanal kültürü yaratmaktadır (Castells, 2007, s. 486).

1980’lerden günümüze, giderek daha hızlanan ve yoğunlaşan bu küreselleşme olgusu ve süreci, ülkeler için firsatların yanı sıra tehditlerde taşımaktadır. Küreselleşme sürecinde kazananlar olduğu gibi kaybedenler de olmaktadır. Küreselleşme yalnızca ekonomik bir olgu değildir. Küreselleşme, başta ekonomi olmak üzere, siyasal, sosyal ve kültürel alanda köklü değişimlere neden olan bir olgudur (Adıgüzel, 2011, s. 58).

"Küreselleşme" olarak adlandırılan süreç; küresel piyasaları geliştirecek yetenek ve hareketliliğe sahip guruplar ile hem bu olanakları olmayan hem de kuralsızlaştırılmış piyasaların genişlemesini toplumsal istikrar ve köklü bir şekilde yerleşmiş normlara istinaden, karşısında olanlar arasında derin bir fay hattını ortaya çıkarmaktadır. Sonuç olarak, işçiler, emekliler ve çevreciler gibi piyasa ile toplumsal guruplar arasında şiddetli bir gerilim ortaya çıkarken bu iki gurup arasında kalan hükümetler yer almaktadır (Rodrik, 2014, s. 448). Küreselleşme ulus devletlerin düzenleyici ve yeniden dağıtımı sağlayıcı kurumları inşa etme kabiliyetini de ortadan kaldırmakta ve bunu aynı zamanda güçlü ulusal kurumların değerini artırarak yapmaktadır. Sosyal sigorta ihtiyacı arttıkça sosyal güvenlik ağlarını finanse etmek daha da zorlaşmaktadır. İhtiyatı denetim önem kazandıkça finansal aracılar ulusal düzenlemelerden kaçınma kabiliyetini artırmaktadırlar (Rodrik, 2009, s. 201-202).

Küreselleşme olgusu sermaye önündeki engelleri kaldırmaktadır. Bu yüzden liberalleşme, denetimsizleştirme, özelleştirme sloganlarını ön plana çıkarmaktadır. Özetle sömürüyü sınırlayan duvarları yıkmak, önüne konmuş barajları aşmak üzere bir saldırıya geçmiş durumdadır. Sömürünün derinleşmiş ve daha geniş bir alana yayılması bırakın evrenselliğin gerçekleşmesini, tam da evrenselliğin inkarıdır (Başkaya, 2015, s. 107).

Küreselleşme karşıtı düşüncelerin başını çeken tartışmalardan en önemlisinin yoksul ülkelerin gittikçe yoksullaştığı, zengin ülkelerinde gittikçe zenginleştiği tezidir. Bu konu son on yılın ekonomik büyüme araştırmalarının en önemli araştırma konularından birisi olmuştur. Sonuç olarak zengin-yoksul arasındaki bu yakınlaşma sadece zengin ülkeler için geçerlidir ve zengin ülkelerin kişi başına düşen gelir düzeylerinin birbirlerine yakınlaştıkları kabul edilmektedir (Çelik, 2012;63).

Küreselleşme, ya da dünya ekonomilerinin daha yakın entegrasyonu, başka hiçbir yerde siyaset piyasa güçlerini küreselleşme alanında olduğu kadar şekillendiremez. Ulaşım ve iletişim masraflarının düşmesi küreselleşmeyi ne kadar teşvik ettiyse, oyunun kurallarındaki değişmeler de bir o kadar etkili olmuştur. Bunlar arasında ticaretin ve sermayenin ülkeler arası akışının önündeki engellerin azaltılması ön plandadır. Gerek ticaretin küreselleşmesi gerekse piyasaların küreselleşmesi gittikçe artan bir eşitsizlik sürecine de katkıda bulunmuştur (Stiglitz, 2012, s. 114).

\section{KÜRESELLEŞMEYİ HIZLANDIRAN FAKTÖRLER; BÍLGİ EKONOMISINDE VE TEKNOLOJIDE GELIŞMELER}

Yirmi birinci yüzyılın ilk çeyreğinde olan dünyada gelişmiş ülkeler bilgi ekonomisi haline dönüşürken, gelişmekte olan ülkelerin bir kısmı bilgi ekonomisine sahip olma, diğer bir kısmı ise sanayi toplumu olma uğraşı içindedirler. Diğer yandan gelişmekte olan ülkelerin bir kısmı ise hala yapısal değişimin ortaya çıkardığı sorunları çözmeye çalışmaktadırlar (Şanlısoy, 510 
2016, s. 2185). Bilgi sürekli olarak kendi kendini yığılımlı bir şekilde yenileyen sınırsız bir üretim faktörüdür. Kendi kendini yığılımlı olarak sürekli yenileyen bilgi; sanayi toplumuna göre gerçekleştirilmiş olan ekonomi biliminin tanımını da değiştirmektedir. Sanayi toplumu azalan verimler yasasına bağlı olarak, ekonominin "kıt kaynakların sınırsız ihtiyaçlar arasında paylaşılmasını inceleyen bir bilim dalı”, olarak tanımlanması, bilgi toplumunda geçerliliğini yitirmektedir. Çünkü bilgi ekonomisinde temel üretim faktörü olan bilgi, artık kıt kaynak değildir. Buna bağlı olarak da azalan verimler yasası geçerliliğini yitirmekte, aksine artan bilgi ile artan verimler yasası geçerli hale gelmektedir (Şanlısoy, 2016, s. 2186). Bilgi toplumundaki bir başka önemli özellik ise mal üretiminden hizmet üretimine doğru bir kaymanın görülmesidir. Aslında hizmet sektörü zaten tüm ekonomilerde her zaman mevcuttur. Ancak sanayi toplumunda hizmetlerin niteliği daha yerel ve mal üretiminde yardımcı konumundadır. Sanayi sonrası toplumunda ise eğitim, sağlık, sosyal hizmetler gibi insani hizmetler ve bilgisayar, sistem analizi, bilimsel araştırma-geliştirme (Ar-Ge) gibi mesleki hizmetler yoğunluk kazanmıştır (Çeken, 2016, s. 102). Teknik ilerlemeler araştırma ve geliştirme yoluyla, yaparak ve öğrenerek yapıldığında önemli bir gelişme yaratmaktadır. Özel bir üretim metodundan yararlanarak, firmalar nasıl daha iyi üretim yapabileceğini öğrenir ve üretim maliyetlerini düşürmeye çalışır. Teknik ilerlemenin belli bir üretim tipiyle alakalı olduğu bir yerde, gelecek nesiller için açılan firsatlar sadece araştırma konusunda değil, hangi mal ve hizmetlerin üretileceği ve nasıl üretileceği konusunda seçimlere bağlıdır. $\mathrm{Bu}$ yüzden bu kararların varsayımlarla değil bilinçli bir şekilde ve geniş paydaşlarla birlikte karar verilmesi önemlidir (Atkinson, 2018, s. 78). Bilgi artık ülkelerin, şirketlerin ve bireylerin de temel rekabet alanı haline gelmiştir. Bilgi temelli ekonomi, iş gücü talebini küresel ölçekte dönüştürmektedir. Fiziksel yeteneklerin yerini bilginin kullanımı, ham maddelerin dönüştürülmesi ve ucuz emek istihdamının yerini ise teknolojik uygulamalar almıştır. Özellikle BİT (Bilgi İşlem Teknolojileri) uygulamaları ile bu duruma uygun kaliteli insan kaynağı gelinen süreçte değişime uğramıştır (Uçkan, 2012. s. 58). Bugün bilgiye dayalı bir ekonomik sistem, küreselleşmeyi hızlandıran bir faktör olarak, yeni teknolojilerin temel dayanağı haline gelmiştir. Bilgiye değer vermek, yaymak, geliştirmek, üretmek, dünya ekonomisinde küreselleşmeyi çok daha hızlandıran bir fonksiyon olarak görülmektedir. Bilgi ve iletişim teknolojilerinde meydana gelen gelişmeler bir yandan küreselleşmeyi hızlandırırken, diğer yandan da küreselleşmeyle birlikte bilginin daha hızlı yayılmasına neden olmaktadir.

Küreselleşme sürecinde ülkelerin ekonomik gelişim sınıflamasında bilgi ekonomisi açısından değerlendirilebilmesi için dikkate alınacak başlıca göstergeler; dünya genelinde ülkelere, bölgelere ve gelir guruplarına göre; bilimsel makale yayınları, araştırma ve geliştirme (ARGE) harcamaları, yüksek teknoloji harcamaları, patent başvuruları, yeni marka tescil başvuruları, endüstriyel tasarımlar, küresel yenilik ve rekabetçilik sıralaması, ihracat ve ithalat gelişimi ve GSYH büyüklük sıralaması gibi kriterler dünya ekonomisi içerisindeki konumlarını göstermesi açısından önemlidir. Çalışmanın bundan sonraki bölümlerinde bu kriterlerin incelenmesi ve dünya ekonomik gelir guruplarına ve ülkelere göre gelişimi ele alınmaktadır.

\section{KÜRESELLEŞEN DÜNYADA SERMAYE HAREKETLERİ VE DOĞRUDAN YABANCI YATIRIMLAR}

1980'lerden itibaren uygulanan iktisat politikaları sonucu serbestleşen sermaye ve mal hareketleri tüm dünya ekonomileri üzerinde farklı etkiler meydana getirmiştir. İktisat 
literatüründe de sıklıkla tartışma konusu olan neoliberal iktisat politikalarının ülkelerin gelir guruplarına göre yansımaları değerlendirilmesi gereken önemli bir konudur. Bu bölümde özellikle serbestleşen sermaye hareketlerinin ülke gurupları açısından nasıl bir seyir izlediğinin görülmesi açısından aşağıdaki tablo;1'de yıllara göre yabancı doğrudan sermaye akımlarının GSYH içindeki oranlarını 2000'den 2018'e kadar olan bir zaman aralığında gerçekleşme oranları verilmektedir. İlk olarak yüksek gelir gurubu ülkelerine yönelik doğrudan yabancı sermaye akımlarının GSYH içindeki oranlarına bakıldığında 2000'de $\% 5.1$ 'den başlayan süreç 2018'de \%1.09 ile sonuçlanan ve yıllar aralığında zaman zaman dalgalı bir seyir izlemesine rağmen azalan bir eğilimdedir. Yüksek orta gelir gurubunda ise 2000 'de \%2.96 ile başlayan süreç y1llar itibariyle sürekli yükselerek devam etmiş 2013'ten itibaren ise 2018 'e kadar azalma eğiliminde ve \%1.87 ile bitmiştir. Bu durum aynı zamanda orta üstü ekonomilerin 2010'lardan itibaren sermaye ihraç eden ülkelere dönüşmesinin de nedenlerindendir. Düşük ve orta gelir gurubunda ise 2000'de \%2.47 ile başlayan oransal değişim süreç içerisinde artarak ve dalgalı bir seyir izlemesine rağmen 2018'de ilk iki gurubun üstünde bir oranla bitirmiştir. Tablodan da görüldügü gibi 2000'lerden itibaren 2010'ların başına kadar hem yüksek orta gelir gurubu hem de düşük ve orta gelir gurubu ülkelere yönelik sermaye hareketleri yükselerek sürmüştür. 2010'lardan itibaren ise her iki gelir gurubuna yönelik sermaye hareketlerinin artış hızında bir azalma olsa da düşük ve orta gelir gurubu ülkelere yönelik sermaye hareketleri sürmektedir. Sermaye hareketlerin ve özellikle doğrudan yabancı yatırımların bu ülkeler için önemi teknoloji transferinin de asıl unsuru olmasındandır. Çünkü sermaye hareketlerinin serbestleşmesi sonucu artan doğrudan yabancı yatırımlar bu ülkelerde hem yabancıların hem de yerleşiklerin teknolojik yatırımlara yönelimi yükselmektedir. Yabancı yatırımların atışıyla paralel yükselen Ar-Ge harcamaları, teknolojik yatırımları, patent ve marka tescil başvuruları gibi gelişmeler bu ülkelerin dünya içerisindeki konumlarının yükselmesine neden olmaktadır.

Tablo 1. Yabancı Doğrudan Yatırımların (FDI) Küresel Dünya Gelir Guruplarına Göre Dağılımı (2000-2018)

\begin{tabular}{|c|c|c|c|c|c|c|c|c|c|c|}
\hline $\begin{array}{l}\text { Gösterge Türü-Yabancı Doğrudan } \\
\text { Yatırımlar / GSYİH }\end{array}$ & \multicolumn{6}{|c|}{$\begin{array}{l}\text { Foreign direct investment. net inflows } \\
\text { (\% of GDP) }\end{array}$} & \multirow[b]{2}{*}{2006} & \multirow[b]{2}{*}{2007} & \multirow[b]{2}{*}{2008} & \multirow[b]{2}{*}{2009} \\
\hline $\begin{array}{l}\text { Dünya Gelir Grupları / World } \\
\text { Income Groups }\end{array}$ & 2000 & 2001 & 2002 & 2003 & 2004 & 2005 & & & & \\
\hline High Income /Yüksek Gelir Gurubu & 5.11 & 2.67 & 2.09 & 1.77 & 2.15 & 3.39 & 4.55 & 5.89 & 3.90 & 2.26 \\
\hline $\begin{array}{l}\text { Upper middle income / Orta Yüksek } \\
\text { Gelir Gurubu }\end{array}$ & 2.96 & 3.13 & 2.87 & 2.64 & 3.02 & 3.33 & 3.53 & 4.01 & 3.65 & 2.49 \\
\hline $\begin{array}{l}\text { Low \& Middle Income / Düşük ve } \\
\text { Orta Gelir Gurubu }\end{array}$ & 2.47 & 2.70 & 2.52 & 2.32 & 2.64 & 3.06 & 3.33 & 3.77 & 3.61 & 2.51 \\
\hline $\begin{array}{l}\text { Gösterge Türü-Yabancı Doğrudan } \\
\text { Yatırımlar / GSYİH }\end{array}$ & \multicolumn{6}{|c|}{$\begin{array}{l}\text { Foreign direct investment. net inflows } \\
\text { (\% of GDP) }\end{array}$} & & & & \\
\hline $\begin{array}{l}\text { World Income Groups / Dünya Gelir } \\
\text { Gurubu }\end{array}$ & 2010 & 2011 & 2012 & 2013 & 2014 & 2015 & 2016 & 2017 & 2018 & \\
\hline High Income / Yüksek Gelir Gurubu & 2.76 & 3.21 & 2.67 & 2.67 & 2.45 & 4.26 & 4.18 & 2.59 & 1.09 & \\
\hline $\begin{array}{l}\text { Upper Middle Income / Orta Yüksek } \\
\text { Gelir Gurubu }\end{array}$ & 3.22 & 3.21 & 2.74 & 2.87 & 2.30 & 2.27 & 2.12 & 1.83 & 1.87 & \\
\hline $\begin{array}{l}\text { Low \& Middle Income / Düşük ve } \\
\text { Orta Gelir Gurubu }\end{array}$ & 2.99 & 3.02 & 2.62 & 2.71 & 2.27 & 2.32 & 2.08 & 1.88 & 1.90 & \\
\hline
\end{tabular}

Kaynak: https://tradingeconomics.com/india/capital-flows, http://wdi.worldbank.org/table/6.9 


\section{KÜRESELLEŞEN DÜNYADA BİLIM VE TEKNOLOJİ GELIŞ̧IM GÖSTERGELERİ}

Toplumsal dinamiğin belirleyenleri olarak öne çıkan teknoloji, bilim ve dünya görüşlerinin, mekan ve zaman boyutları içinde şekillendiği biçim ve izlediği yol, o toplumun uygarlık seviyesini göstermektedir. Geleneksel değerlere dayalı bir sosyal bir anlayış seviyesi, bilim ve teknoloji üretmekte verimsiz kalırken, bilime dayalı bir sosyal yaşam seviyesi ise bilgi ekonomisi ve teknoloji yönlü bir sisteme dönüşme firsatı vermektedir (Kutlu \&Tosunoğlu, 2017, s. 5). Bu yüzden yeni teknolojik imkanların hızlandırdığı küreselleşmenin etkilerinin incelenmesinde önemli olan ilk kriter; dünya genelinde patent başvurularının ekonomik gelir guruplarına göre gelişim sürecinin gözlemlenmesidir. Aşağıdaki tablo; 2'de, 2007 ile 2017 arasında ekonomik gelir guruplarına göre sınıflandırılan patent başvuru sayıları verilmektedir. Tabloda da görüldüğü gibi; 2007 y1lında 1,433,000 patent başvurusuyla küresel dünyanın yüksek gelir gurubundaki ülkeler ilk sırada yer almaktadır. Aynı gelir gurubunun (High Income) patent başvuru sıralaması 2017'de 1,555,600'e yükselmiştir. İlk gelir gurubu içinde yer alan ülkeler aynı zamanda gelişmiş ekonomiler olarak da tanımlanmaktadır. İkinci sırada yer alan gelir gurubuna göre yani ortanın üstü gelir (Upper Middle Income) gurubunda olan ülkelerin uluslararası patent başvuru siralaması 2007'de, 372,300 iken 2017'de 1,524,400'e çıtığı görülmektedir. Son yıllarda özellikle orta üstü gelir seviyesindeki ülkelerin patent başvurularının yüksek gelir gurubu ülkeler seviyesinden çok daha hızlı artması araştırma konumuzun da temelini oluşturan küreselleşmenin fırsat yaratma özelliği açısından çok önemli bir nokta olarak görülmelidir. Bu ülkeler kategorik olarak iktisat literatüründe gelişen piyasalar, ya da diğer bir ifadeyle gelişmekte olan ekonomiler olarak tanımlanmaktadır. Özellikle bu rakamlar da göstermektedir ki 1980’lerden sonra değişen iktisadi değişim (neoliberal serbestleşme politikaları ve küreselleşme etkisi) ve teknolojik gelişmelerin de itici fonksiyonuyla, gelişmekte olan ülkelerin bir kısmında teknolojiye yönelim açısından çok hızlı bir değişim meydana geldiği görülmektedir. Yine aynı tabloda yer alan düşük orta gelir gurubunda (Low Middle Income) 2007'de 61,300 olan patent başvuru sayısı 2017'de 78,900 'a çıkmıştır. Düşük gelir (Low Income) gurubunda ise 2007'de 8,400 olan patent başvuru sayısı 2017 'de ise 10,000 'e çıkmıştır. Düşük orta ve düşük gelir guruplarında patent başvuru sayılarının çok yüksek olmadığı tablodan da açıkça görülmektedir. Küresel dünya genelindeki patent başvuru sayıları ise 2007'de 1,875,000'den, 2017'de 3,168,900'e yükselmiştir. Küresel dünya genelinde patent başvuru sayısı 2007'den 2017'ye yaklaşı iki kat artmaktadır. Bu artışın büyük bölümü yukarıda da verilen rakamlardan da görüldüğü gibi yüksek ve yüksek orta gelir gurubundaki ülkelerin başvurularından kaynaklanmaktadır. Bu tablo da göstermektedir ki yüksek gelir ve yüksek orta gelir gurubundaki ülkeler dünya ekonomisi içerisindeki ekonomik varlıklarını yükseltmektedirler.

Tablo 2. Dünya Küresel Patent Başvuruları Gelir Gruplarına Göre 2007-2017

\begin{tabular}{|l|r|r|}
\hline \multicolumn{3}{|c|}{ Global Patent Aplications By Income Group 2007 and 2017 } \\
\hline Income Group (Gelir Grupları) & $\mathbf{2 0 0 7}$ & \multicolumn{1}{c|}{$\mathbf{2 0 1 7}$} \\
\hline Yüksek Gelir Grubu - High Income & $1,433,000$ & $1,555,600$ \\
\hline Yüksek Orta Gelir - Upper Middle-Income & 372,300 & $1,524,400$ \\
\hline Orta Gelir Grubu- Lower Middle-Income & 61,300 & 78,900 \\
\hline Düşük Gelir Grubu - Low Income & 8,400 & 10,000 \\
\hline
\end{tabular}




\begin{tabular}{|l|r|r|}
\hline Dünya Geneli - World & $\mathbf{1 , 8 7 5 , 0 0 0}$ & $\mathbf{3 , 1 6 8 , 9 0 0}$ \\
\hline
\end{tabular}

https://www.wipo.int/edocs/pubdocs/en/wipo_pub_941_2018.pdf

Küreselleşen dünya ekonomisinde bilim temelli ve yüksek teknoloji endüstrileri ekonomik büyümenin ve rekabet gücünün önemli bir bileşeni olarak görülmektedir. Aşağıdaki tablo $3 \mathrm{a}$ ve tablo 3b'de ki veriler ışığında ise bu açıkça görülmekte ve yüksek orta seviyedeki ülkeler dünya ekonomisi içindeki varlıkları bilim ve teknolojideki ilerlemelerine bağlı olarak artırmaktadırlar. Küreselleşen dünyadaki teknolojik gelişmeler ve serbestleşme politikalarının hızlandırdığı bilgi akımı dünya ekonomisinin gelir guruplarında farklı sonuçlar meydana getirmiştir. Aşağıda tablo; 3a ve 3b'de dünya ekonomik gelir guruplarına göre, 2018 yılındaki bilim ve teknikteki yayın miktarı, ihraç mallarına yönelik yüksek teknoloji payı ve 2010 ile 2018 arasındaki Ar-Ge harcamaları, görülmektedir. Bilimsel yayınlar bakımından yüksek gelir gurubunun liderliği olmasına rağmen orta üstü gelir gurubu ülkelerin de bilimsel yayınlar konusundan göze çarpan bir seviyede yükselmiş olduğu açıkça görülmektedir. Araştırma ve geliştirme üzerine yapılan harcamaların GSYH içindeki oranları da aynı yönde bir seyir izlemektedir. Gelir guruplarına göre yapılabilecek bir değerlendirme sonucunda 2018 yılı itibariyle yüksek teknoloji dayalı ihracat yüzdeleri dikkate alındığında göze çarpan bir farklılık ortaya çıkmaktadır. 2018 yılı itibariyle yüksek teknolojiye bağlı ihracat yüzdeleri; yüksek orta gelir gurubu ülkelerde \%23.5 olarak gerçekleşirken, yüksek gelir gurubu ülkelerde \%20.2 olarak gerçekleşmiştir. Düşük orta gelir gurubundaki ülkelerde ise bu oran $\% 17.2$ olarak görülmektedir. Dünya genelinde ise ortalama \%20.8 olarak görülmektedir. Dünya genelinde gelir guruplarına göre yapılan değerlendirmelerde Ar-Ge harcamaları, Bilimsel yayın miktarları, Teknolojik yatırımları ve yüksek teknolojiye dayalı ihracat yapıları ülkelerin de dünya ekonomileri sıralamalarında yerlerini ortaya koymaktadır. Aşağıdaki tablo $3 \mathrm{a}$ ve $3 \mathrm{~b}$ 'de ki veriler de bunu ortaya koymaktadır.

Tablo 3a. Küresel Bilim ve Teknolojik Gelişme Göstergeleri (2010-2018)

\begin{tabular}{|c|c|c|c|c|c|}
\hline & \multicolumn{2}{|c|}{$\begin{array}{l}\text { Research and Development } \\
\text { (R \&D) } \\
\text { Araştırma ve Geliştirme } \\
\text { (Ar-Ge) }\end{array}$} & \multirow{2}{*}{ 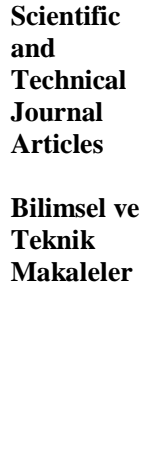 } & \multirow{2}{*}{$\begin{array}{l}\text { Expenditures } \\
\text { for R \& D } \\
\text { \% of GDP } \\
\text { Ar-Ge } \\
\text { Harcamaları } \\
\text { GSYH } \\
\text { Yüzdesi }\end{array}$} & \multirow{2}{*}{$\begin{array}{l}\text { High } \\
\text { Technology } \\
\text { Exports } \\
\text { \% of } \\
\text { Manufactured } \\
\text { Exports } \\
\text { Yüksek } \\
\text { Teknoloji } \\
\text { İhracatın } \\
\text { Üretimdeki } \\
\text { Yüzdesi }\end{array}$} \\
\hline & $\begin{array}{l}\text { Researchers } \\
\text { Ful Time } \\
\text { Equivalent Per } \\
\text { Million People } \\
\text { Araştırmacılar- } \\
\text { Milyon Kişi } \\
\text { Başına Tam } \\
\text { Zamanlı } \\
\text { Çalışma }\end{array}$ & $\begin{array}{l}\text { Technicians } \\
\text { Full Time } \\
\text { Equivalent Per } \\
\text { Million People } \\
\text { Teknisyenler- } \\
\text { Milyon Kişi } \\
\text { Başına Tam } \\
\text { Zamanlı } \\
\text { Çalışma }\end{array}$ & & & \\
\hline & $2010-2018$ & $2010-2018$ & 2018 & $2010-2018$ & 2018 \\
\hline World - Dünya & 1,411 & --- & $2,554,373$ & 2.27 & 20.8 \\
\hline $\begin{array}{l}\text { East Asia \& Pasific } \\
\text { Uzak Doğu Asya ve } \\
\text { Pasific }\end{array}$ & 1,623 & --- & 866,663 & 2.51 & 34.5 \\
\hline $\begin{array}{l}\text { Europa \& Central } \\
\text { Asia } \\
\text { Avrupa ve Merkez } \\
\text { Asya }\end{array}$ & 3,373 & 871 & 794,018 & 1.98 & 15.5 \\
\hline
\end{tabular}

514 


\begin{tabular}{|c|c|c|c|c|c|}
\hline $\begin{array}{l}\text { Latin America \& } \\
\text { Caribbean } \\
\text { Latin Amerika ve } \\
\text { Karayibler }\end{array}$ & 580 & 558 & 108,228 & 0.71 & 14.3 \\
\hline $\begin{array}{l}\text { Middle East \& North } \\
\text { Africa } \\
\text { Orta Doğu ve Kuzey } \\
\text { Afrika }\end{array}$ & --- & --- & 119,302 & 0.93 & 6.8 \\
\hline $\begin{array}{l}\text { North America } \\
\text { Kuzey Amerika }\end{array}$ & 4,404 & --- & 482,867 & 2.74 & 18.3 \\
\hline $\begin{array}{l}\text { South Asia } \\
\text { Güney Asya }\end{array}$ & 253 & 73 & 154,139 & 0.65 & 8.7 \\
\hline $\begin{array}{l}\text { Sub- Saharan Africa } \\
\text { Sahra Altı Afrikası }\end{array}$ & --- & --- & 29,479 & --- & 4.4 \\
\hline $\begin{array}{l}\text { Low Income } \\
\text { Düşük Gelirliler }\end{array}$ & --- & --- & 5,308 & --- & --- \\
\hline $\begin{array}{l}\text { Lower Middle } \\
\text { Income } \\
\text { Alt Orta Gelirliler } \\
\end{array}$ & 288 & 98 & 213,355 & 0.58 & 17.2 \\
\hline $\begin{array}{l}\text { Upper Middle } \\
\text { Income } \\
\text { Üst Orta Gelirliler }\end{array}$ & 1,149 & --- & 893,169 & 1.73 & 23.5 \\
\hline $\begin{array}{l}\text { Hıgh Income } \\
\text { Yüksek Gelirliler }\end{array}$ & 4,351 & --- & $1,450,446$ & 2.59 & 20.2 \\
\hline
\end{tabular}

Kaynak: http://wdi.worldbank.org/table/5.13

Tablo; 3b. Küresel Bilim ve Teknolojik Gelişme Göstergeleri (2010-2018)

\begin{tabular}{|c|c|c|c|c|c|}
\hline & \multicolumn{2}{|c|}{$\begin{array}{l}\text { Patent Applications } \\
\text { Field } \\
\text { Patent Başvuruları Alan }\end{array}$} & \multirow{2}{*}{$\begin{array}{l}\text { Trademark } \\
\text { Applications } \\
\text { filed (by count) } \\
\text { Tescilli Marka } \\
\text { Başvuruları } \\
\text { (Sayısal } \\
\text { Olarak) } \\
\begin{array}{c}\text { Non Residence } \\
\text { Yabancilar }\end{array}\end{array}$} & \multicolumn{2}{|c|}{$\begin{array}{l}\text { Industrial Design Applications } \\
\text { Filed (By Count) } \\
\text { Endüstriyel Tasarım } \\
\text { Başvuruları (Sayısal Olarak) }\end{array}$} \\
\hline & $\begin{array}{l}\text { Residence } \\
\text { Yerleşikler }\end{array}$ & $\begin{array}{c}\text { Non } \\
\text { Residence } \\
\text { Yabancilar } \\
\end{array}$ & & $\begin{array}{l}\text { Residence } \\
\text { Yerleşikler }\end{array}$ & $\begin{array}{l}\text { Non Residence } \\
\text { Yabancılar }\end{array}$ \\
\hline & 2018 & 2018 & 2018 & 2018 & 2018 \\
\hline World - Dünya & $2,294,847$ & 845,358 & $2,065,166$ & $1,040,764$ & 155,084 \\
\hline $\begin{array}{l}\text { East Asia \&Pasific } \\
\text { Uzak Doğu Asya ve Pasific }\end{array}$ & $1,820,380$ & 345,332 & 756,318 & 788,452 & 55,479 \\
\hline $\begin{array}{l}\text { Europa \& Central Asia } \\
\text { Avrupa ve Merkez Asya }\end{array}$ & 141,496 & 52,244 & 561,018 & 182,910 & 50,402 \\
\hline $\begin{array}{l}\text { Latin America \& } \\
\text { Caribbean } \\
\text { Latin Amerika ve } \\
\text { Karayibler }\end{array}$ & 8,148 & 45,943 & 203,684 & 7,489 & 7,415 \\
\hline $\begin{array}{l}\text { Middle East \& North } \\
\text { Africa } \\
\text { Orta Doğu ve Kuzey } \\
\text { Afrika }\end{array}$ & 16,856 & 15,926 & 153,845 & 23,168 & 6,007 \\
\hline $\begin{array}{l}\text { North America } \\
\text { Kuzey Amerika }\end{array}$ & 289,444 & 343,858 & 275,623 & 23,598 & 30,357 \\
\hline $\begin{array}{l}\text { South Asia } \\
\text { Güney Asya }\end{array}$ & 17,007 & 34,911 & 60,632 & 11,506 & 4,016 \\
\hline Sub- Saharan Africa & --- & --- & --- & --- & --- \\
\hline
\end{tabular}




\begin{tabular}{|l|r|r|r|r|r|}
\hline Sahra Alt Afrikası & & & & \\
\hline $\begin{array}{l}\text { Low Income } \\
\text { Düşük Gelirliler }\end{array}$ & --- & --- & -- & -- \\
\hline $\begin{array}{l}\text { Lower Middle Income } \\
\text { Alt Orta Gelirliler }\end{array}$ & 22,866 & 51,856 & 248,937 & 29,975 & 14,655 \\
\hline $\begin{array}{l}\text { Upper Middle Income } \\
\text { Üst Orta Gelirliler }\end{array}$ & $1,452,221$ & 233,643 & 763,815 & 759,733 & 48,845 \\
\hline $\begin{array}{l}\text { Hıgh Income } \\
\text { Yüksek Gelirliler }\end{array}$ & 819,240 & 559,683 & $1,025,704$ & 250,234 & 91,315 \\
\hline
\end{tabular}

Kaynak: http://wdi.worldbank.org/table/5.13.

\section{DÜNYA EKONOMISINDE GELİR GURUPLARINA GÖRE DIŞ TICARET GELIŞMELERI}

Son yıllarda, esasen hem teknolojik ve bilimsel gelişmeler hem de bölgesel ticaret antlaşmaları yoluyla dış ticareti sınırlandırıcı engellerin ortadan kaldırılmasına yönelik çabalar, küresel ekonominin dönüşümünü hızlandırmıştır (Benli, 2019, s. 51). Bu dönüşüm süreci, bir taraftan, toplumların birbirine entegre olmasını sağlarken, diğer taraftan ise, toplumlar üzerinde farklılaştırıcı sonuçların ortaya çıkmasına neden olmuştur. İleri teknolojiye yönelen ekonomiler, dünya ekonomileri içinde rekabet üstünlüğüne sahip konumuna yükselirlerken aynı anda da teknolojinin itici gücü olmuşlardır. Önceki bölümlerde vurgulandığı gibi serbestleşmenin hızlandırdığı küreselleşme olgusu ve teknolojinin itici gücüyle bilgiye ulaşımın da kolaylaşması, dünya genelinde bazı ülkelerin, bilimsel çalışmalar, Ar-Ge faaliyetleri ve yüksek teknoloji yatırımlarına yönelik kaynak yoğunluğunun artırmasına neden olmuştur. Özellikle 1980'lerden sonra değişen dünya ekonomik sisteminin yarattığı bu firsatı olumlu değerlendiren bazı ülkeler ekonomik gelişmişlik seviyelerini ve dünya ticareti içindeki rekabet gücünü de artırarak konum farklılığına erişmişlerdir. Aynı konu üzerinde devamla bu gelişimi destekleyen ilk gösterge tablo; 4'de görülmektedir. Bu tabloda iki gurup olarak ele alınan sınıflamada (Gelişmiş ve Gelişmekte olan Ekonomiler) 2001-2010 ve 2011-2020 (2019 ve 2010 tahmin olarak) arası ihracat ve ithalat gelişmeleri yüzdesi ve 2011'den 2018'e kadar yıllar itibariyle meydana gelen değişimlerin verilmektedir. İlk olarak 2001-2010 arasına bakıldığında gelişmiş ekonomilerin ihracat-ithalat değişim yüzdesi sırasıyla \%3.8 ve \%3.5 olarak gerçekleşmiştir. 2011-2020 arasında ise yine ihracat ve ithalat sırasıyla \%3.1 ve \%3.1 olarak gerçekleştiği görülmektedir. Aynı zaman aralıklarında ise gelişmekte olan ülkelerin ihracat ve ithalat değişim yüzdeleri ise şu şekilde gerçekleşmektedir. 2001-2010'aralığında ihracat-ithalat; \%8.0 ve \%9.3 ve 2011-2020'de ise \%3.9 ve \%4.3 olarak gerçekleşmektedir. Her iki ekonomik gurubu karşılaştırıldığında gelişmekte olan ülkelerin dış ticarette rekabet gücünün yükseldiğini göstermektedir. $\mathrm{Bu}$ sonuçlar da yukarıdaki verileri destekleyen sonuçlar olarak görülebilir. Gelişen piyasaların dünya ekonomisi içindeki gücünün yükseldiğinin kanıtı olan bu rakamları destekleyen bir diğer gösterge ise seçilmiş bazı ekonomilerin GSYH gelişmelerinin de incelenmesi gerekmektedir. Bir sonraki tablo da bununla ilgili olacaktır.

Tablo: 4. Dünya Ekonomisinde Ekonomik Gruplara Göre İhracat ve İthalat Yüzde Değişmeleri (2001-2018)

\begin{tabular}{|l|c|c|c|c|c|c|c|c|c|c|}
\hline Dünya İhracat ve İthalatı Yıllık Ortalama Değişim Yüzdesi \\
\hline Ticaret Hacmi - İhracat & $\begin{array}{c}2001 \\
-10\end{array}$ & $\begin{array}{c}2011 \\
-20^{*}\end{array}$ & 2011 & 2012 & 2013 & 2014 & 2015 & 2016 & 2017 & 2018 \\
\hline
\end{tabular}




\begin{tabular}{|l|c|c|c|c|c|c|c|c|c|c|}
\hline Gelișmiş Ekonomiler & 3.8 & 3.1 & 6.4 & 2.7 & 2.6 & 3.2 & 3.2 & 1.5 & 4.7 & 3.1 \\
\hline $\begin{array}{l}\text { Gelişmekte Olan } \\
\text { Ekonomiler }\end{array}$ & 8.0 & 3.9 & 8.0 & 3.9 & 4.7 & 2.7 & 1.1 & 2.9 & 7.0 & 3.8 \\
\hline Ticaret Hacmi - İthalat & & & & & & & & & & \\
\hline Gelișmiș Ekonomiler & 3.5 & 3.1 & 6.0 & 1.1 & 2.3 & 3.4 & 3.8 & 2.2 & 5.0 & 3.5 \\
\hline $\begin{array}{l}\text { Gelişmekte Olan } \\
\text { Ekonomiler }\end{array}$ & 9.3 & 4.3 & 11.4 & 5.2 & 4.7 & 2.7 & -0.7 & 2.2 & 7.8 & 5.0 \\
\hline
\end{tabular}

Kaynak: IMF World Economic Outlook, Global Manufacturing Downturn, Rising Trade Barriers 2019 October ISBN:978-1-51351-616-5, www.imfbookstore.org, www.elibrary.imf.org, *Tahmini değerleme

Aşağıdaki tablo 5'deki veriler önceki bölümlerde verilen tablolar ile bir paralellik arz etmektedir. Tabloda da görüldüğü gibi 2010-2018 arası verilen değerler açısından yüksek gelir gurubu ilkelerin dünya ihracatı 2010 'da 10,541,757'den 2018'de 13,016,483'e çıkarak toplamda \%21 değişim meydana getirmiştir. Orta üstü gelir gurubu ülkeleri ise aynı zaman aralığında 3,867,552'den 5,235,545'e yükselerek \%26'lık bir değişimle sonuçlanmıştır. Orta altı gelir gurubunda ise 923,051'den 1,257,557'ye çıkarak \%27'lik bir değişime neden olmuştur. Düşük gelir gurubu ülkeleri ise 68,019 'den 66,883 'e gerileyerek eksi \%2'lik düşüşle sonuçlanmıştır. Dünya geneli ortalaması ise 15,400,350'den 19,600,450'ye yükselerek \%22 oranında bir değişimle sonuçlanmıştır. Burada öne çıkan sonuç orta üstü ve orta altı gelir gurubu ülkelerinin dünya ihracat gelişimleri hem yüksek gelir gurubunun üstünde hem de dünya ortalamasının üzerinde oluşudur. Bu durum da göstermektedir ki orta üstü ve orta altı gelir gurubu ülkelerinin dünya ticaretinde rekabet gücünün yükselmektedir.

Tablo: 5. Dünya Ekonomileri Gelir Guruplarına Göre İhracat Gelişimi (2010-2018)

\begin{tabular}{|l|r|r|r|}
\hline $\begin{array}{l}\text { Dünya Kalkınma Göstergeleri Milyon Dolar (USD) } \\
\text { (World Development Indicators) }\end{array}$ & \multicolumn{2}{|c|}{ İhracat (Exports) } & \multicolumn{1}{|c|}{2018} \\
\hline Millions Dolar (\$) & 2010 & $\begin{array}{c}2010-2018 \% \\
\text { Değişim }\end{array}$ \\
\hline $\begin{array}{l}\text { Yüksek Gelir Gurubu Ekonomileri (High Income } \\
\text { Economies) }\end{array}$ & $10,541,757$ & $13,016,483$ & $21 \%$ \\
\hline $\begin{array}{l}\text { Orta Üstü Gelir Gurubu Ekonomileri (Upper Middle } \\
\text { Income) }\end{array}$ & $3,867,552$ & $5,235,545$ & $26 \%$ \\
\hline $\begin{array}{l}\text { Orta Alt1 Gelir Gurubu Ekonomileri (Lower Middle } \\
\text { Income) }\end{array}$ & 923,051 & $1,275,557$ & $27 \%$ \\
\hline Düşük Gelir Gurubu Ekonomileri (Low Income) & 68,019 & 66,883 & $-2 \%$ \\
\hline Dünya (World) & $15,400,350$ & $19,600,450$ & $22 \%$ \\
\hline
\end{tabular}

Kaynak: http://wdi.worldbank.org/table/4.4

\section{9. ÜLKELERE GÖRE GAYRI SAFİ YURTIÇİ HASILA (GSYH) SIRALAMASI}

Bilgi ekonomisinin ve teknolojik gelişmelerin hızlandırdığı küreselleşmenin dünya ekonomileri üzerindeki etkisinin değerlendirilmesinde öne çıkan bir başka kriter ise ülkelerin GSYH büyüklüklerinin yıllara göre değişiminin incelenmesi olacaktır. Aşağıdaki tablo; 6a'da 1980, 1985, 1990, 2000, 2007, 2008, 2009 yıllarında gelişmişlik seviyelerine göre seçilen ülkelerin GSYH büyüklükleri verilmiştir. Tabloda seçilen yıllara göre dünya GSYH'sı 1980'de 11,156.37 milyar dolardan, 2009'da 60,435.58 milyar dolara yükselmiştir. Dünya genelinde GSYH, 29 yılda altı misli arttığı görülmektedir. Aynı yıllar içinde gelişmiş ekonomiler sınıfından seçilmiş ülkeler olarak GSYH büyüklüklerinin değişimi, $\mathrm{ABD}$; 
yaklaşık altı misli, Birleşik Krallık; yaklaşık dört misli, Japonya; yaklaşık altı misli, Almanya; yaklaşık dört misli, Fransa; yaklaşık dört misli, Avusturya; yaklaşık yedi misli, Finlandiya; yaklaşık beş misli, Kanada; dört misli, olarak gerçekleştiği görülmektedir. Aynı yıllar aralığında gelişmekte olan ülkeler açısından rakamlar incelendiğinde ise, Çin; yaklaşık on altı misli, İrlanda; yaklaşık on misli, Brezilya; yaklaşık on misli, Arjantin; yaklaşık on bir misli, Türkiye; yaklaşık yedi misli, Polonya; dokuz misli, Meksika; yaklaşık dört misli, Malezya; yaklaşık dokuz misli, Hindistan; yaklaşık beş misli, Tayland; yaklaşık dokuz misli, Güney Kore; yaklaşık on beş misli, Güney Afrika ise yaklaşık üç misli büyümüştür. 20. Yüzyılın son çeyreği ve 21. Yüzyılın başlarını gösteren bu tabloda gelişmekte olan ülkeler bazı istisna ülkeler haricinde genellikle gelişmiş ülkelerden çok daha fazla büyüdüğü görülmektedir. 1980'li yıllardan itibaren başlayan neoliberal iktisat politikalarının etkisiyle serbestleşen piyasalar ve iletişim ve ulaşım teknolojilerindeki yüksek ivmeli yenilikler, gelişmekte olan ülkelerin ekonomik performansı üzerinde çok daha pozitif etkiler yarattığı görülmektedir.

Tablo 6a. Dünya Geneli ve Ülkelere Göre Gayri Safi Yurt İçi Hasıla (GSYH) Sıralaması 19802009

\begin{tabular}{|c|c|c|c|c|c|c|c|c|}
\hline & \multirow{2}{*}{$\begin{array}{c}\begin{array}{l}\text { Milyar } \\
\text { Dolar }\end{array} \\
1980\end{array}$} & \multicolumn{2}{|c|}{ Billion US Dolars } & \multicolumn{3}{|c|}{$\begin{array}{l}\text { GDP Gross Domestic } \\
\text { Product }\end{array}$} & \multirow[b]{2}{*}{2008} & \multirow[b]{2}{*}{2009} \\
\hline & & 1985 & 1990 & 1995 & 2000 & 2007 & & \\
\hline $\begin{array}{l}\text { Dünya } \\
\text { Ekonomisi }\end{array}$ & 11,156 & 12,452 & 23,521 & 31,024 & 33,858 & 58,159 & 63,775 & 60,435 \\
\hline \multicolumn{2}{|c|}{ Gelişmiş Ekonomiler } & & & & & & & \\
\hline ABD & 2,857 & 4,339 & 5,963 & 7,639 & 10,252 & 14,451 & 14,712 & 14,448 \\
\hline İngiltere & 604 & 536 & 1,191 & 1,336 & 1,651 & 3,085 & 2,934 & 2,403 \\
\hline Japonya & 1,105 & 1,398 & 3,132 & 5,449 & 4,887 & 5,700 & 6,157 & 6,203 \\
\hline Almanya & 853 & 661 & 1,598 & 2,588 & 1,948 & 3,425 & 3,744 & 3,407 \\
\hline Fransa & 702 & 557 & 1,272 & 1,602 & 1,366 & 2,660 & 2,929 & 2,697 \\
\hline Avustralya & 162 & 174 & 323 & 378 & 399 & 947 & 1,055 & 998 \\
\hline Belçika & 124 & 84 & 201 & 289 & 238 & 472 & 520 & 485 \\
\hline Finlandiya & 53 & 56 & 141 & 134 & 125 & 255 & 284 & 252 \\
\hline İtalya & 482 & 458 & 1,171 & 1,171 & 1,145 & 2,206 & 2,400 & 2,191 \\
\hline Kanada & 276 & 366 & 596 & 605 & 744 & 1,468 & 1,552 & 1,376 \\
\hline \multicolumn{9}{|c|}{ Gelişmekte Olan Ekonomiler } \\
\hline & 1980 & 1985 & 1990 & 1995 & 2000 & 2007 & 2008 & 2009 \\
\hline Çin Halk Cum. & 305 & 312 & 398 & 736 & 1,214 & 3,571 & 4,604 & 5,121 \\
\hline İrlanda & 21 & 21 & 48 & 69 & 100 & 270 & 276 & 236 \\
\hline Brezilya & 145 & 226 & 455 & 786 & 655 & 1,396 & 1,694 & 1,667 \\
\hline Arjantin & 226 & 95 & 153 & 280 & 308 & 287 & 363 & 334 \\
\hline Türkiye & 96 & 92 & 207 & 233 & 273 & 675 & 764 & 644 \\
\hline Polonya & 56 & 70 & 62 & 139 & 171 & 429 & 533 & 440 \\
\hline
\end{tabular}




\begin{tabular}{|l|r|r|r|r|r|r|r|r|}
\hline Meksika & 228 & 217 & 290 & 360 & 707 & 1,052 & 1,109 & 900 \\
\hline Malezya & 26 & 34 & 47 & 96 & 102 & 202 & 242 & 211 \\
\hline Hindistan & 189 & 237 & 326 & 366 & 476 & 1,238 & 1,224 & 1,365 \\
\hline Tayland & 33 & 40 & 88 & 169 & 126 & 262 & 262 & 281 \\
\hline $\begin{array}{l}\text { Güney Kore } \\
\text { Cum. }\end{array}$ & 67 & 103 & 288 & 574 & 576 & 1,172 & 1,047 & 943 \\
\hline Güney Afrika & 82 & 59 & 115 & 155 & 136 & 299 & 287 & 297 \\
\hline
\end{tabular}

Kaynak: https://knoema.com/atlas/World/GDP

Tablo; 6b' de ise 2010 ile 2018 aralığında gerçekleşen GSYH büyüklüklerinin değişimleri görülmektedir. Tabloda da görüldüğü gibi dünya GSYH verileri 2010'da 66,073.38 milyar dolardan, 2018 sonu itibariyle 84,929.51 milyar dolara, yani sekiz yıllık bir süre sonunda yaklaşık bir değer ile yüzde on sekiz civarında bir büyüklüğe ulaşmıştır. Aynı yıllar aralığında gelişmiş ekonomiler olarak sırasıyla ABD (US); 14,992.05 milyar dolardan 20,580.25 milyar dolara yükselmiştir. Sırasıyla UK (Birleşik Krallık); 2,455.31'den 2,828.83 milyar dolara, Japonya (JAPAN); 5,700.10 milyar dolardan 4,971.77 milyar dolara düşmüş, Almanya; 3,402.44 milyar dolardan, 3,951.34 milyar dolara, Fransa; 2,645.35 milyar dolardan, 2,780.15 milyar dolara yükselmiştir. Tablodan da görüleceği gibi gelişmiş ekonomilerin 2010 ile 2018 arasındaki GSYH değişimi gelişmekte olan ülkelere kıyasla çok yüksek değildir. Diğer yandan gelişmekte olan ekonomilerin bazıları açısından durum çok daha farklı görülmektedir. Örneğin Çin üzerinden bu değişim belirgin bir şekilde görülebilir. Çin'in 2010'da GSYH's1 6,066.35 milyar dolardan, 2018'de 13,368.07 milyar dolara yükselmiştir. İki tarih arasındaki yüzdesel değişim iki kattan fazladır. Gelişmekte olan ekonomiler içinde yüksek büyüme oranları yakalamış diğer ülkeler; İrlanda, Tayland, Hindistan, Malezya, Güney Kore, Meksika'dır. Tabloda görülen diğer gelişmekte olan ülkeler ise GSYH yıllık büyüme oranları açısından çok göze batan değişim olduğunu söylemekle beraber ekonomik olarak büyüme performanslarını sürdürmüşlerdir. Bu durum küreselleşen dünya ekonomisinde bazı ülkelerin küreselleşmenin firsatlarını değerlendirerek yüksek büyüme oranlarını yakaladığı anlamına gelirken, bazı ülkelerin ise yüksek büyüme rakamlarını yakalayamadıkları görülmektedir. Küreselleşmenin yarattığg firsat mı? tehdit mi? sorusunun değerlendirilmesi bazıları için firsat olduğu cevabına neden olurken, bazı ülkeler için ise küreselleşmenin sonuçları bakımından bir tehdit olduğu ileri sürülebilir. Araştırmanın konusu gereği küreselleşmenin ve bilgi ekonomisinin gelişmiş ve gelişmekte olan ekonomiler üzerindeki etkileri ve sonuçları açısından bir değerlendirme olduğundan özellikle az gelişmiş ekonomiler çalışmaya dahil edilmemiştir. Zaten çalışma alanı içinde belirlenen tarihler aralığında (1980-2018) az gelişmiş ekonomilerin göze çarpan bir gelişmesi olmamıştır.

Tablo 6b. Dünya Geneli ve Ülkelere Göre Gayri Safi Yurt İçi Hasıla (GSYH) Sıralaması 20102018

Milyar USD * (Billion USD) * GSYH Gayri Safi Yurt İçi Hasıla (GDP Gross Domestic Product)

\begin{tabular}{|l|c|c|c|c|c|c|c|r|r|}
\hline & $\mathbf{2 0 1 0}$ & $\mathbf{2 0 1 1}$ & $\mathbf{2 0 1 2}$ & $\mathbf{2 0 1 3}$ & $\mathbf{2 0 1 4}$ & $\mathbf{2 0 1 5}$ & $\mathbf{2 0 1 6}$ & $\mathbf{2 0 1 7}$ & $\mathbf{2 0 1 8}$ \\
\hline Dünya & 66,073 & 73,311 & 74,690 & 76,842 & 78,944 & 74,779 & 75,823 & 80,262 & 84,929 \\
\hline Gelişmiş Ekonomiler \\
\hline ABD & 14,992 & 15,542 & 16,197 & 16,784 & 17,527 & 18,224 & 18,715 & 19,519 & 20,580 \\
\hline
\end{tabular}




\begin{tabular}{|c|c|c|c|c|c|c|c|c|c|}
\hline İngiltere & 2,455 & 2,635 & 2,677 & 2,755 & 3,036 & 2,897 & 2,669 & 2,640 & 2,828 \\
\hline Japonya & 5,700 & 6,155 & 6,203 & 5,155 & 4,850 & 4,389 & 4,926 & 4,859 & 4,971 \\
\hline Almanya & 3,402 & 3,748 & 3,529 & 3,733 & 3,890 & 3,362 & 3,468 & 3,664 & 3,951 \\
\hline Fransa & 2,647 & 2,864 & 2,685 & 2,811 & 2,856 & 2,439 & 2,472 & 2,591 & 2,780 \\
\hline Avustralya & 1,251 & 1,513 & 1,569 & 1,518 & 1,457 & 1,235 & 1,267 & 1,386 & 1,420 \\
\hline Belçika & 484 & 527 & 498 & 521 & 531 & 456 & 469 & 495,95 & 532,27 \\
\hline Finlandiya & 248 & 273 & 256 & 270 & 273 & 232 & 239 & 252 & 274 \\
\hline İtalya & 2,128 & 2,278 & 2,074 & 2,131 & 2,155 & 1,833 & 1,869 & 1,950 & 2,075 \\
\hline Kanada & 1,617 & 1,793 & 1,828 & 1,846 & 1,805 & 1,556 & 1,530 & 1,649 & 1,712 \\
\hline \multicolumn{10}{|c|}{ Gelișen Ekonomiler } \\
\hline & 2010 & 2011 & 2012 & 2013 & 2014 & 2015 & 2016 & 2017 & 2018 \\
\hline Çin & 6,066 & 7,522 & 8,570 & 9,635 & 10,534 & 11,226 & 11,221 & 12,062 & 13,368 \\
\hline Írlanda & 222 & 237 & 224 & 238 & 258 & 291 & 300 & 335 & 382 \\
\hline Brezilya & 2,207 & 2,613 & 2,464 & 2,471 & 2,456 & 1,799 & 1,795 & 2,052 & 1,867 \\
\hline Arjantin & 424 & 527 & 579 & 611 & 563 & 642 & 556 & 642 & 519 \\
\hline Türkiye & 772 & 832 & 873 & 950 & 934 & 859 & 863 & 852 & 771 \\
\hline Polonya & 479 & 528 & 500 & 524 & 545 & 477 & 471 & 526 & 585 \\
\hline Meksika & 1,057 & 1,180 & 1,201 & 1,274 & 1,314 & 1,170 & 1,077 & 1,156 & 1,222 \\
\hline Malezya & 258 & 302 & 318 & 327 & 342 & 301 & 301 & 318 & 358 \\
\hline Hindistan & 1,708 & 1,823 & 1,827 & 1,856 & 2,039 & 2,103 & 2,289 & 2,652 & 2,718 \\
\hline Tayland & 341 & 370 & 397 & 420 & 407 & 401 & 412 & 455 & 504 \\
\hline Güney Kore & 1,144 & 1,253 & 1,278 & 1,370 & 1,484 & 1,465 & 1,500 & 1,623 & 1,720 \\
\hline Güney Afrika & 375 & 416 & 396 & 366 & 350 & 317 & 296 & 349 & 368 \\
\hline
\end{tabular}

Kaynak https://knoema.com/atlas/World/GDP, *Rakamlara 3 sifir eklenecektir.

\section{SONUÇ VE DEĞERLENDİRMELER}

Yirminci yüzyılın son çeyreğinden itibaren uygulanan neoliberal ekonomik politikalar ve hızlanan teknolojik gelişmeler sonucunda serbestleşen sermaye ve mal hareketleri ve bilişim sektöründeki yenilikler ile önemi artan bilgi ekonomisinin sonuçları, dünya genelinde az gelişmiş, gelişmekte ve gelişmiş ekonomiler üzerinde köklü değişimler yaratmıştır. Küreselleşmenin getirdiği bu olanaklar sayesinde ülkelerin iç kaynakların yetmediği durumlarda dış kaynaklara başvurulması, teknoloji ve sermaye yetersizliği sorunlarına karşı ise teknoloji ve sermaye transferleri yapılması bu ekonomilerin kalkınmasında ve büyümesinde olumlu katkıları olmuştur. Çünkü dünya ekonomisinde gelişmiş, gelişmekte ve az gelişmiş olan ekonomiler arasındaki farklılaşmanın nedenlerinin başında finansal kaynakların eksikliği, yatırımların azlığı, teknolojik bilgi yetersizlikleri gelmektedir. Tartışmaların merkezinde yer alan küreselleşme süreci, dünya ekonomisinde gelişmiş ekonomiler lehine fayda yaratmaya devam etmekle beraber, 1980'lerden itibaren değişen iktisat politikaları (neo-liberal iktisat uygulamaları) sayesinde dünya ekonomileri içinde 520 
önceki yüzyıl boyunca az gelişmiş veya gelişmekte olan ülkeler statüsünde yer alan bazı ekonomiler açısından önemli farklılıklar meydana getirdiği de yadsınamaz bir gerçeklik olarak görülmektedir. Bu çalışmada seçilen göstergeler yardımıyla teknolojinin gelişmesiyle önemi artan bilgi ekonomisinin de etkisiyle hızlanan küreselleşmenin etkilerinin incelenmesi için örnek ülkeler karşılaştırması yapılarak küreselleşmenin dünya ekonomileri üzerinde bir tehdit mi, yoksa firsat eşitliği yaratan bir olgu mu olduğu sorgulanmıştır. Çalışmada özellikle seçilmiş bazı gelişmiş ve gelişmekte olan ülkelerin karşılaştırılması yapılmış ve farklı sonuçlara ulaşılmıştır. Küreselleşmenin ve bilgi ekonomisinin gerçeklerini kabul edip, ülke düzeyinde yapılanmalarını bu yönde kurgulamayı başarmış olan ülkeler küreselleşmenin firsatlarından da faydalanarak ekonomilerini hızla büyütmeyi başarmışlardır. Özellikle 2000'li yıllardan itibaren dünya genelinde GSYH büyüklükleri karşılaştırıldığında gelişmekte olan ekonomiler, gelişmiş ekonomilerden çok daha hızlı büyüdüğü görülmektedir. 1980'li y1llara kadar dünün gelişmekte veya az gelişmiş ülkeleri olarak görülen orta ve orta üstü gelir gurubu ülkeleri son otuz yılda gelişmiş ekonomilerle başa baş rekabet edebilir bir ekonomiler haline dönüşmüşlerdir. Çalışmadaki tablolar bunu açıkça göstermektedir. Diğer yandan gelişmiş ekonomiler, son yıllarda dış ticarette bu yeni ekonomilere karşı bazı ticaret mallarında rekabet avantajlarını kaybetmekle beraber hala dünyanın merkezinde ve dünyanın en büyük ekonomileri olmayı sürdürmektedirler. Yani geçmişin gelişmiş ekonomileri küreselleşmenin nimetlerinden hala faydalanmakla beraber dünya ticaretinde bu yeni yükselen ekonomilere karşı rekabet avantajları sürekli azalma eğilimindedir. Gelişmiş ekonomilerle, yukarıdaki seçilmiş olan orta ve orta üstü gelişmekte olan ekonomiler arasındaki GSYH büyüme oranları da bunu açıkça göstermektedir. Özzellikle 2000'li yıllardan itibaren GSYH büyüme ivmelerinde bu görülmektedir. Yeni dünya düzeninde neoliberal iktisadi düzende uygulanan ekonomi politikalarının gelişmekte olan ülkelere büyük olanaklar yaratmasına rağmen bu firsatları değerlendiren bazı ülkeler ekonomik gelişmişlik seviyelerini hızla yükseltmişler, fakat bu firsatları değerlendiremeyen diğer ülkeler ise hala az gelişmişlik veya orta altı gelir seviyesi kalmaya devam etmişlerdir. Gelişmiş ekonomiler açısından çıkarılacak sonuç ise özellikle ABD ve bazı gelişmiş Avrupa ülkeleri küreselleşmenin ekonomik firsatlarından faydalanmakla beraber, dünya ekonomisinde ortaya çıkan yeni paydaşları nedeniyle pazar bayları azalmış ve GSYH büyüme hızları yavaşlamıştır. Küreselleşen dünyada bilgi teknolojilerini ve bilgi ekonomisini doğru analiz edip ekonomik entegrasyonunu başarılı bir şekilde yöneten ülkeler küreselleşmeyi fırsata çeviren ve başaran ülkeler olmuşlardır. Başaramayan ülkeler ise küreselleşme sürecinde geride kalmaya devam etmişlerdir. Ya da bir başka ifadeyle küreselleşme bir tehdit mi, firsat mıdır sorusuna verilebilecek cevap; farklı bir bakış açısıyla dünya ekonomisindeki serbestleşme uygulamalarının ve teknolojideki gelişmelerin sonucunda, teknolojik gelişmeleri ve bilgi ekonomisini doğru yöneten ekonomiler bu durumu bir firsat olarak değerlendirirlerken, bu gelişmelere rağmen teknolojik gelişmeleri ve bilgi ekonomisini doğru yönetemeyen ekonomiler açısından ise, teknolojinin ve bilgi ekonomisinin hızlandırdığı küreselleşme bir tehdit unsuru olarak sürmeye devam etmektedir.

\section{KAYNAKÇA}

ACAR, M. (2018). Düzleştirici ve Özgürleştirici Bir Süreç Küreselleşme. Konya: Literatürk Academia.

ADIGUZEL, M. (2011). Bilgi Toplumu ve Küreselleşme Bağlamında Küresel Rekabet Ortamı Ankara: Nobel Akademik Yayıncılık Eğitim Danışmanlık Tic. LTD. ŞTİ. 
ALKAN, A. (2009). Küresel Sistemik Krizin Anatomisi. İstanbul: Scala Yayıncılık.

ATKINSON, A. (2018). Eşitsizlik Ne Yapılabilir? Ankara: Efil Yayınevi.

BASKAYA, F. (2015). Sömürgecilik Emperyalizm Küreselleşme. İstanbul: Öteki Yayınevi.

BENLI, M. (2019). "The Long-Run Effects of Trade and Income on Carbon Emissions: Evidence from Heterogeneous Dynamic Panel of Developing Countries". Balkan and Near Eastern Journal of Social Sciences.

BRONK, R. (2010). Romantik Ekonomist Ekonomide Hayal Gücü, Çev. D. B. CENKCİLER, Efil Yayınevi. Ankara. ISBN:978-605-4334-39-1.

CASTELlS, M. (2014). Küresel Enformasyon Kapitalizmi, (Ed. D. Held \& A. Mc. Grew.), Küresel Dönüşümler Büyük Küreselleşme Tartışması. Ankara. Phoenix Yayınevi.s. 367-395.

CASTELLS, M. (2013). Enformasyon Çağı:Ekonomi, Toplum ve Kültür, Çev. Ebru Kılıç, İstanbul Bilgi Üniversitesi Yayınları, İstanbul. ISBN:978-605-399-012-3.

CEKEN, C. K. (2016). "Türkiye'nin Bilgi Ekonomisi Performansı (2004-2014 Dönemi)". Dicle Üniversitesi Hukuk Fakültesi Dergisi, Cil 21, Sayı 34, s. 99-139.

CELIK, M. Y. (2012). "Boyutlarıyla ve Farklı Algılarıyla Küreselleşme". Kütahya, Dumlupınar Üniversitesi Sosyal Bilimler Dergisi, Cilt 1, Sayı 32, s. 57-74.

CIGGDEM, G. (2014). Küresel Ekonomik Kriz ve Etkileri ve Medya. Kocaeli. Umuttepe Yayınları.

DOLLAR, D., \& KRAAY, A. (2014). Zenginliğin Yayılması. (Ed. D. HELD \& A. MC. GREW), Küresel Dönüşümler Büyük Küreselleşme Tartışması, Ankara: Phoenix Yayınevi.s. 530-540.

ERKAN, H. (2017). "Bilgi Toplumu ve Özellikleri" Bilgi Ekonomisi, Edit. E. KUTLU \& B.TUĞBERK TOSUNOĞLU, Anadolu Üniversitesi Yayınları

FREEMAN, C., \& SOETE, L. (2003). Yenilik İktisadı, Çev. E. TÜRKCAN. Ankara: TÜBİTAK Yayınları / Akademik Dizi.

GALLINO, L. (2012). Küreselleşme ve Eşitsizlik. Ankara: Dost Kitabevi.

GIDDENS, A. (2014). "Modernliğin Küreselleşmesi". (Ed. D. HELD \& A. MC. GREW), Küresel Dönüşümler Büyük Küreselleşme Tartışması, Ankara, Phoenix Yayınevi.s. 81-87.

GONGEN, M. A. (2013). "Küreselleşmenin Ekonomik Boyutu Küreselleşmeyi Yöneten Üç Ana Kurum: IMF, Dünya Bankası, Dünya Ticaret Örgütü". SDÜ Fen Edebiyat Fakültesi Sosyal Bilimler Dergisi.

HELD, D., \& MC GREW, A. (2014). "Büyük Küreselleşme Tartışması", (Ed. D. HELD \& A. MC. GREW.), Küresel Dönüşümler Büyük Küreselleşme Tartışması, Ankara: Phoenix Yayınevi.s. 7-71

HIRST, P., \& THOMPSON, G. (2007). Küreselleşme Sorgulanıyor. (Çev. ERDEM. Ç. \& YÜCEL. E.), Ankara: Dost Kitabevi Yayınları. 
HOBSBAWN, E. (2017). İmparatorluk Çağı, (Çev. ASLAN, V.), Ankara: Dost Kitabevi.

ISIK, Y. (2007). Küresel Sorunların Çözümünde Bilgi Ekonomisinin Açtığı Perspektifler, 14. Kasım 2007 İstanbul Kongresi Sunumu.

KARAHAN, O. (2006). "Üretim Faktörü Olan Bilgi", Bilgi Ekonomisi, Ekin Kitabevi, Bursa, ISBN 975-8768-81-6.

KARGI, N. (2006). Bilgi Ekonomisi, Ekin Kitabevi, Bursa. ISBN:975-8768-81-6.

KEVUK, S. (2006). Bilgi Ekonomisi, Journal of Yaşar Üniversity, 1(4), 319-350.

KEOHANE, R., \& NYE JR. J. S. (2014). "Küreselleşme: Yeni Olan Ne? Olmayan Ne?" (Ed. D. HELD \& A. MC. GREW), Küresel Dönüşümler Büyük Küreselleşme Tartışması, Ankara: Phoenix Yayınevi.s. 97-106.

KOSEOGLU, N. (2002). Küreselleşme ve Milli Hayat. İstanbul: Ötüken Neşriyat.

MILANOVIC, B. (2018). Küresel Eşitsizlik Küreselleşme Çağı İçin Yeni Bir Yaklaşım. Çev. M. UZBAY \& M. PİRILİ, Efil Yayınevi. Ankara. ISBN:978-605-2294-18-5.

ONDER, I. (2011). İktisat Üzerine Düşünceler. İstanbul: Yordam Kitap.

OZCAC, M \& BOZDAGLIOĞLU, E.Y. \& KUCUKKAYA, H. (2018). "Geçiş Ekonomilerinde Doğrudan Yabancı Yatırımların Ekonomik Büyüme Üzerine Etkisi: Dinamik Panel Yeri Analizi", Business And Economics Research Journal, 10(1) : 41 53, 2019. ISSN :2619-9491

RODRIK, D. (2006). İktisadı Anlamak, (Çev. MADENCİ, C.), Ankara: Efil Yayınevi.

RODRIK, D. (2009). Tek Ekonomi Çok Reçete, (DOMANIÇ, N.), Ankara: Efil Yayınevi.

RODRIK, D. (2011). Akıllı Küreselleşme, (Çev. AKSU, B), Ankara: Phoenix Kitap.

ROUBINI, N., \& MIHM, S. (2011). Kriz Ekonomisi Dünya Ekonomisinin Çöküşü ve Geleceği. (Çev. Tezcan, I.) İstanbul: Pegasus Yayınları.

SANLISOY, S. (2016). "Bilgi Ekonomisinin Uluslararası Gelir Dağılımı Üzerine Etkileri". Uluslararası Sosyal Araştırmalar Dergisi, Cilt. 9, Sayı. 43, S, 2185-2203.

STIGLITZ, J. E. (2012). Eşitsizliğin Bedeli Bugünün Bölünmüş Toplumu Geleceğimizi Nasıl Tehlikeye Atıyor, (Çev. İŞLER, O), İstanbul: İletişim Yayınları.

UCKAN, O. (2006). "Bilgi Politikası ve Bilgi Ekonomisi: Verimlilik, İstihdam, Büyüme ve Kalkınma". İstanbul, Bilgi Dünyası, Cilt; 7 Sayı; 1, s. 23-48. 